\title{
Introduction to project DUNE, a DUst experiment in a low Nutrient, low chlorophyll Ecosystem
}

\author{
C. Guieu ${ }^{1,2}$, F. Dulac ${ }^{3,4}$, C. Ridame ${ }^{5,6}$, and P. Pondaven ${ }^{7}$ \\ ${ }^{1}$ CNRS-INSU, UMR7093, LOV, Observatoire océanologique, 06230, Villefranche/mer, France \\ ${ }^{2}$ Sorbonne Universités, UPMC Univ Paris 06, UMR7093, LOV, Observatoire océanologique, 06230, Villefranche/mer, France \\ ${ }^{3}$ Laboratoire des Sciences du Climat et de l'Environnement (LSCE), UMR8212 CEA-CNRS-UVSQ, 91191 Gif-Sur-Yvette, \\ France \\ ${ }^{4}$ Laboratoire Interuniversitaire des Systèmes Atmosphériques (LISA), Université Paris VII, 94010 Créteil, France \\ ${ }^{5}$ CNRS-INSU/IRD/ MNHN/UPMC, UMR7159, LOCEAN, Laboratoire d'Océanographie et du Climat: Expérimentation et \\ Approches Numériques, 75252, Paris, France \\ ${ }^{6}$ Sorbonne Universités, UPMC Univ Paris 06, UMR7159, LOCEAN, 75252 Paris, France \\ ${ }^{7}$ Université Européenne de Bretagne, Université de Brest, UMR6539 LEMAR, Institut Universitaire Européen de la Mer, \\ IUEM; Technopôle Brest Iroise, Place Nicolas Copernic, 29280 Plouzané, France
}

Correspondence to: C. Guieu (guieu@obs-vlfr.fr)

Received: 8 July 2013 - Published in Biogeosciences Discuss.: 26 July 2013

Revised: 29 November 2013 - Accepted: 3 December 2013 - Published: 29 January 2014

\begin{abstract}
The main goal of project DUNE was to estimate the impact of atmospheric deposition on an oligotrophic ecosystem based on mesocosm experiments simulating strong atmospheric inputs of eolian mineral dust.

Our mesocosm experiments aimed at being representative of real atmospheric deposition events onto the surface of oligotrophic marine waters and were an original attempt to consider the vertical dimension after atmospheric deposition at the sea surface.

This introductory paper describes the objectives of DUNE and the implementation plan of a series of mesocosm experiments conducted in the Mediterranean Sea in 2008 and 2010 during which either wet or dry and a succession of two wet deposition fluxes of $10 \mathrm{~g} \mathrm{~m}^{-2}$ of Saharan dust have been simulated based on the production of dust analogs from erodible soils of a source region. After the presentation of the main biogeochemical initial conditions of the site at the time of each experiment, a general overview of the papers published in this special issue is presented. From laboratory results on the solubility of trace elements in dust to biogeochemical results from the mesocosm experiments and associated modeling, these papers describe how the strong simulated dust deposition events impacted the marine biogeochemistry. Those multidisciplinary results are bringing new insights into the
\end{abstract}

role of atmospheric deposition on oligotrophic ecosystems and its impact on the carbon budget. The dissolved trace metals with crustal origin - $\mathrm{Mn}, \mathrm{Al}$ and $\mathrm{Fe}$ - showed different behaviors as a function of time after the seeding. The increase in dissolved $\mathrm{Mn}$ and $\mathrm{Al}$ concentrations was attributed to dissolution processes. The observed decrease in dissolved Fe was due to scavenging on sinking dust particles and aggregates. When a second dust seeding followed, a dissolution of $\mathrm{Fe}$ from the dust particles was then observed due to the excess $\mathrm{Fe}$ binding ligand concentrations present at that time. Calcium nitrate and sulfate were formed in the dust analog for wet deposition following evapocondensation with acids for simulating cloud processing by polluted air masses under anthropogenic influence. Using a number of particulate tracers that were followed in the water column and in the sediment traps, it was shown that the dust composition evolves after seeding by total dissolution of these salts. This provided a large source of new dissolved inorganic nitrogen (DIN) in the surface waters. In spite of this dissolution, the typical inter-elemental ratios in the particulate matter, such as $\mathrm{Ti} / \mathrm{Al}$ or $\mathrm{Ba} / \mathrm{Al}$, are not affected during the dust settling, confirming their values as proxies of lithogenic fluxes or of productivity in sediment traps. DUNE experiments have clearly shown the potential for Saharan wet deposition to 
modify the in situ concentrations of dissolved elements of biogeochemical interest such as $\mathrm{Fe}$ and also P and N. Indeed, wet deposition yielded a transient increase in dissolved inorganic phosphorus (DIP) followed by a very rapid return to initial conditions or no return to initial conditions when a second dust seeding followed. By transiently increasing DIP and DIN concentrations in $\mathrm{P}$ - and $\mathrm{N}$-starved surface waters of the Mediterranean Sea, wet deposition of Saharan dust can likely relieve the potential $\mathrm{P}$ and/or $\mathrm{N}$ limitation of biological activity; this has been directly quantified in terms of biological response. Wet deposition of dust strongly stimulated primary production and phytoplanktonic biomass during several days. Small phytoplankton $(<3 \mu \mathrm{m})$ was more stimulated after the first dust addition, whereas the larger size class $(>3 \mu \mathrm{m})$ significantly increased after the second one, indicating that larger-sized cells need further nutrient supply in order to be able to adjust their physiology and compete for resource acquisition and biomass increase. Among the microorganisms responding to the atmospheric inputs, diazotrophs were stimulated by both wet and dry atmospheric deposition, although $\mathrm{N}_{2}$ fixation was shown to be only responsible for a few percent of the induced new production. Dust deposition modified the bacterial community structure by selectively stimulating and inhibiting certain members of the bacterial community. The microbial food web dynamics were strongly impacted by dust deposition. The carbon budget indicates that the net heterotrophic character (i.e., ratio of net primary production to bacteria respiration $<1$ ) of the tested waters remained (or was even increased) after simulated wet or dry deposition despite the significant stimulation of autotrophs after wet events. This indicates that the oligotrophic tested waters submitted to dust deposition are a net $\mathrm{CO}_{2}$ source. Nonetheless, the system was able to export organic material, half of it being associated with lithogenic particles through aggregation processes between lithogenic particles and organic matter. These observations support the "ballast" hypothesis and suggest that this "lithogenic carbon pump" could represent a major contribution of the global carbon export to deep waters in areas receiving high rates of atmospheric deposition. Furthermore, a theoretical microbial food web model showed that, all other things being equal, carbon, nitrogen and phosphorus stoichiometric mismatch along the food chain can have a substantial impact on the ecosystem response to nutrient inputs from dusts, with changes in the biomass of all biological compartments by a factor of $\sim 2-4$, and shifts from net autotrophy to net heterotrophy. Although the model was kept simple, it highlights the importance of stoichiometric constrains on the dynamics of microbial food webs.

\section{Context and objectives}

Nutrient cycling controls in part the efficiency of the biological carbon pump through which $\mathrm{CO}_{2}$ is consumed in ocean surface waters and transported to the deep sea as sinking particulate organic carbon (Moore et al., 2013). The interactions between atmosphere and ocean play a key role if we are to understand processes governing nutrient cycles in the ocean and to which extent climate change plays a role in this scheme. In this context, the scientific community pays special attention to atmospheric input of nutrients, which can alter community structure and nutrient cycling in the oceans and therefore modify the efficiency of the ocean to store atmospheric $\mathrm{CO}_{2}$ (Law et al., 2013). Atmospheric deposition is now well recognized as a significant source of $\mathrm{Fe}$ and other nutrients for surface waters of the global remote ocean (Duce et al., 1991; Jickells et al., 2005; Moore et al., 2013) as well as of the Mediterranean (e.g., Loye-Pilot et al., 1990; Bergametti et al., 1992; Quétel et al., 1993; Ridame and Guieu, 2002; Bonnet and Guieu, 2006, Guieu et al., 2010a, Markaki et al., 2010). An unresolved issue in ocean and climate sciences is whether changes in the atmospheric input to the surface ocean can alter the flux of carbon to the deep ocean (Law et al., 2013). This question is of particular interest in the Mediterranean region, a regional hot spot of the global climate change (Giorgi et al., 2006), whereas for the global ocean, a positive trend in both sea surface and deep-water temperatures is being experienced (MERMEX Group 2011).

While the impact of $\mathrm{Fe}$ on productivity has been recognized in high-nutrient, low-chlorophyll (HNLC) oceanic regions through both bioassay experiments (Martin et al., 1994), mesoscale artificial $\mathrm{Fe}$ fertilization experiments (see the syntheses by de Baar et al., 2005, and Boyd et al., 2007) and natural Fe fertilization (Blain et al., 2007), the ecological and biogeochemical effects of atmospheric dust-derived $\mathrm{Fe}$ and macronutrients (N, P) in oligotrophic - i.e., lownutrient, low-chlorophyll (LNLC) - environments are still poorly understood and resulting $\mathrm{C}$ export via fertilization and aggregation processes is not quantified. And yet, these LNLC oceanic regions represent $60 \%$ of the global ocean (Longhurst et al., 1995) and over $50 \%$ of the global oceanic carbon export (Emerson et al., 1997).

The Mediterranean Sea is a typical LNLC region, particularly well suited to tackle the question of the role of atmospheric input: it is an oligotrophic, quasi-enclosed basin that receives a noticeable amount of desert dust considering its rather small surface $\left(\sim 2.5 \times 10^{6} \mathrm{~km}^{2}\right)$ compared to other oceanic areas (Table 1 ).

In the western Mediterranean region, mineral dust is mainly transported from the Sahara in the form of strong pulses (e.g., Loÿe-Pilot et al., 1986; Bergametti et al., 1989a and b; Moulin et al., 1998; Guerzoni et al. 1999). LoÿePilot and Martin (1996) report annual mineral dust deposition fluxes from 4 to $26.2 \mathrm{~g} \mathrm{~m}^{-2}$ (mean $12.5 \mathrm{~g} \mathrm{~m}^{-2} \mathrm{yr}^{-1}$ ) between 1984 and 1994, with events larger than $0.5-1 \mathrm{~g} \mathrm{~m}^{-2}$ 
Table 1. Mineral dust deposition to the ocean.

\begin{tabular}{lrl}
\hline & Tg yr $^{-1}$ & Reference \\
\hline North Atlantic & 202 & Jickells et al. (2005) \\
Indian Ocean & 118 & Jickells et al. (2005) \\
North Pacific & 72 & Jickells et al. (2005) \\
Mediterranean Sea & 40 & Guerzoni et al. (1999) \\
South Pacific & 29 & Jickells et al. (2005) \\
South Atlantic & 17 & Jickells et al. (2005) \\
Arctic Ocean & 5.7 & Shevchenko and Lisitzin (2004) \\
World ocean & 477 & Mahowald et al. (2010) \\
\hline
\end{tabular}

driving the annual fluxes and thus the interannual variability (Fig. 1). In 1984, $40 \%$ of the annual flux fell within three days, and $80 \%$ within three days in 1986. According to the same authors, this deposition is mainly (95\%) associated with wet deposition and may occur only with a few drops of rain, meaning that a high amount of dust can be deposited in timescales of minutes (for example on 17 October 1993, they report a $2.4 \mathrm{~g} \mathrm{~m}^{-2}$ flux coming with only a few drops of rain evaporating immediately). The same orders of magnitude were found in more recent observations reported in Ternon et al. (2010), with an average annual dust flux over 4 years (2003-2007) of $11.4 \mathrm{~g}^{-2} \mathrm{yr}^{-1}$ controlled by wet deposition. The major deposition events reported in the northwestern Mediterranean, amounting to about $22 \mathrm{~g} \mathrm{~m}^{-2}$, were observed at Cap Ferrat, French Riviera, on 26 February 2004 (22.2 $\mathrm{g} \mathrm{m}^{-2}$ corresponding to $88 \%$ of the annual dust deposition that year; Bonnet and Guieu, 2006) and at Ostriconi in Corsica $\left(21.9 \mathrm{~g} \mathrm{~m}^{-2}\right.$ corresponding to $80 \%$ of the annual dust deposition that year; Guieu et al., 2010a).

At the DYFAMED (DYnamique des Flux Atmosphériques en MEDiterranée) site in the remote northwestern Mediterranean, the sedimentation flux from surface waters of particulate manganese $(\mathrm{Mn})$ and aluminum $(\mathrm{Al})$ corresponds to the atmospheric deposition flux on an annual timescale (Davies and Buat-Ménard, 1990), and most of the Fe associated with organic matter sinking from surface waters is provided by atmospheric input (Quétel et al., 1993). Moreover, the Mediterranean Basin continuously receives anthropogenic aerosols from industrial and domestic activities from populated areas around the basin and other parts of Europe, as well as seasonal inputs from biomass burning (Remoudaki et al., 1991a, b; Migon et al., 1991; Bergametti et al., 1992; Guieu et al., 2005, 2010a). As described earlier (MERMEX Group, 2011), the mixing of natural dust aerosols with anthropogenic aerosols might have a positive fertilization effect on biota by bringing both bioavailable $\mathrm{N}$ and $\mathrm{P}$ to the Mediterranean surface waters, particularly during the stratification period. Indeed, when the water column is stratified and characterized by low primary productivity, phosphate and nitrate concentrations are very low (under detection limits of standard methods, namely 20 and $30 \mathrm{nM}$, respectively) and

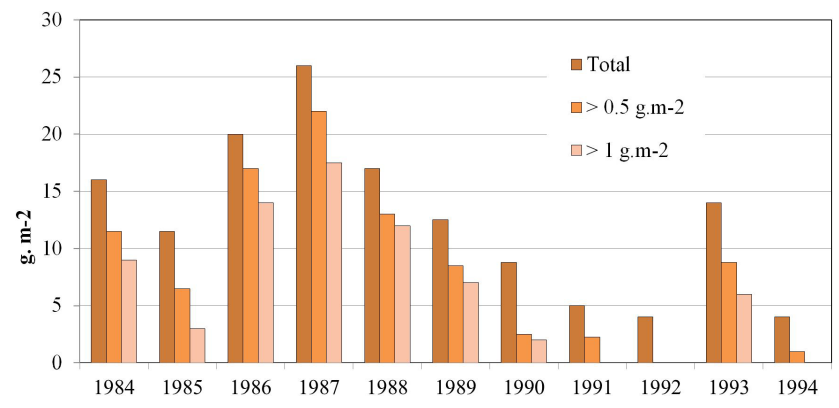

Fig. 1. Ten-year time series of dust deposition in Corsica showing the contribution of events with dust deposition higher than $0.5 \mathrm{~g} \mathrm{~m}^{-2}$ and $1 \mathrm{~g} \mathrm{~m}^{-2}$ to the total annual Saharan dust deposition (reproduced from Loÿe-Pilot and Martin, 1996).

biological activity in the surface waters encounters nitrate limitation and nitrate-phosphate co-limitation (Tanaka et al., 2011). Concerning dissolved Fe (DFe), it becomes depleted after the spring bloom and could also temporarily affect productivity with concentrations as low as $0.2 \mathrm{nM}$ (Sarthou and Jeandel, 2001; Bonnet and Guieu, 2006). Throughout the strong thermal stratification period during summer and fall, a sharp thermocline (10-20 m deep; D'Ortenzio et al., 2005) associated with an efficient pycnocline acts as a physical barrier to vertical transfers, with extremely low diffusion. Moreover, horizontal advection has been shown to be weak in the northwestern Mediterranean Sea (i.e., Andersen and Prieur, 2000). The upwelling of dissolved elements from depth is thus reduced during the stratified period, and the atmosphere becomes the main pathway for supply to the surface layer of both dissolved $\mathrm{N}$ (as shown, for example, during the BOUM cruise in the western Mediterranean; Moutin and Prieur, 2012), P (e.g., Loÿe-Pilot et al., 1990; Bergametti et al., 1992; Migon and Sandroni 1999; Herut et al., 1999; Kouvarakis et al., 2001; Ridame and Guieu, 2002; Markaki et al., 2003; Krom et al., 2004) and Fe (Guieu et al., 2002a, Bonnet and Guieu, 2006). Using Quétel's (1991) data, Dulac et al. (1996) illustrate the strong impact of a Saharan dust deposition event on the particulate Fe concentration profile in the surface layer at the DYFAMED station in the northwestern Mediterranean. Through theoretical calculation and/or bioassay experiments, it has been shown that those inputs can impact both heterotrophic (Thingstad et al., 2005; Pulido-Villena et al., 2008) and autotrophic (including diazotrophs) production in the Mediterranean Sea (Klein et al.,1997; Migon and Sandroni 1999; Ridame and Guieu, 2002; Bonnet et al., 2005; Ridame et al., 2011; Ternon et al., 2011), underlining their capacity to relieve the macro- and micro-nutrient limitations encountered in this area. Other effects different from direct fertilization effects, such as particulate organic carbon (POC) fluxes' mediation by organicmineral aggregation, have been shown to be significant in the Mediterranean Sea: for example, the extreme Saharan event of February 2004, representing a dust flux on the order of 
$22 \mathrm{~g} \mathrm{~m}^{-2}$ in some locations in Corsica and the French Riviera (Bonnet and Guieu, 2006; Ternon et al., 2010), resulted in export at $200 \mathrm{~m}$ in the Ligurian Sea (DYFAMED station) representing $45 \%$ of the total annual POC, compared to an average of $25 \%$ for the whole bloom period that same year. This emphasizes the need to understand the role played by such high Saharan dust deposition in the POC export efficiency both thanks to increased production induced by the input of new nutrients and through organic-mineral aggregation and ballast effect in a dust-rich area such as the northwestern Mediterranean Sea. In this context, the main objective of DUNE was to follow the impacts of a well-characterized mineral dust atmospheric input on an oligotrophic ecosystem in order to answer the following questions:

- How does the introduction of atmospheric particles impact the cycle of chemical elements of major biogeochemical interest such as $\mathrm{C}, \mathrm{P}, \mathrm{N}$ and $\mathrm{Fe}$ ?

- What is the response of viruses, bacteria, phytoplankton and zooplankton in terms of abundance, activity and diversity?

- How is the temporal pattern of the particulate export modified by an intense and brief introduction of atmospheric particles?

- Do dry and wet depositions act in the same way?

- Do deposition fluxes of similar magnitude and duration result in similar impacts, and if so, and why?

In spite of previous efforts, answers to the question of the biological response in LNLC regions and, in particular, in the Mediterranean Sea to atmospheric inputs are still fragmented. To cover this gap, within the DUNE project, we proposed to study the effect of atmospheric input on the oligotrophic Mediterranean ecosystem through artificial mineral dust additions over large in situ mesocosms representative of a significant body of the surface waters in perfectly controlled conditions and taking into account the vertical dimension of the processes involved after dust deposition: such an approach is indeed the strength of the project and was possible thanks to the strong and effective partnership between atmospheric and oceanic scientist partners of DUNE (Guieu et al., 2010b).

\section{The mesocosm strategy}

Our experiments rely on seeding of northern African mineral dust in mesocosms in order to reproduce an intense deposition event and to follow its biogeochemical impact in marine surface waters over about a week. Microcosm experiments are commonly used to study the impact of atmospheric deposition on the biogeochemistry of surface waters (Guieu et al., 2014b, and references within). Because of the small water volumes involved in the microcosm approach (usually a few liters at maximum), confinement issues can rapidly occur, and thus the experimental duration is often a limit (usually 2 days and at most 6 days (Guieu et al., 2014b). Such small volumes also limit the number of parameters that can be measured in stocks and fluxes. Another important limit is that microcosms rely on a homogeneously distributed concentration of added aerosols. Mesocosms present the advantage of enabling studies of processes both as a function of depth and time while the atmospheric particles are sinking. Indeed, due to the significant particulate flux entering the ocean (in particular, a desert dust deposition event), one can expect that there will be different processes such as adsorption/desorption, release of new nutrients, biological uptake and aggregation processes that will take place concurrently during the course of the particles' descent. During DUNE, mesocosm sampling at different depths in a quick sequence allowed us to measure a number of stocks (including nutrients, trace metals, phytoplankton, zooplankton and heterotrophic bacteria biomass concentrations) and fluxes (primary production, bacterial respiration, $\mathrm{N}_{2}$ fixation, export of particulate organic matter). Figure 2 summarizes all the measurements that were performed in the mesocosms at different depths of the captured column water thanks to the large volume considered ( $52 \mathrm{~m}^{3}$ in this work).

\subsection{Representativity of the simulated flux}

As detailed in the introduction, the mean annual dust deposition flux in Corsica during the period 1984-1994 was $12.5 \mathrm{~g} \mathrm{~m}^{-2}$ and was shown to be mainly attributed to pulses $>1 \mathrm{~g} \mathrm{~m}^{-2}$ (Loÿe-Pilot and Martin, 1996; Fig. 1). Strong events $\left(\sim 22 \mathrm{~g} \mathrm{~m}^{-2}\right)$ with a short duration have been recorded in this region more recently in 2001 (Guieu et al., 2010a) and 2004 (Bonnet and Guieu, 2006). During DUNE, we chose to mimic a high, but still realistic, Saharan dust deposition event of $10 \mathrm{~g} \mathrm{~m}^{-2}$ into the mesocosms.

\subsection{Producing dust analog}

In order to reproduce a real Saharan dust deposition by means of a controlled seeding in seawater, it was first necessary to produce hundreds of grams of particulate material identical to the aerosols being deposited at the surface of the ocean. This was achieved by experimental simulation of (i) the production of desert aerosols and (ii) chemical aging mimicking their transport and cloud processing in the atmosphere (Guieu et al., 2010b). Wet and dry depositions were mimicked during different experiments as there is so far no knowledge/evidence of potential differences regarding the impact of those different types of deposition on the biogeochemistry. The detailed methodology has been published in Guieu et al. (2010b) and only a short summary is presented here.

Mineral dust aerosol particles are mainly produced by sandblasting of clay-rich alluvial soils (Prospero et al., 2002). 


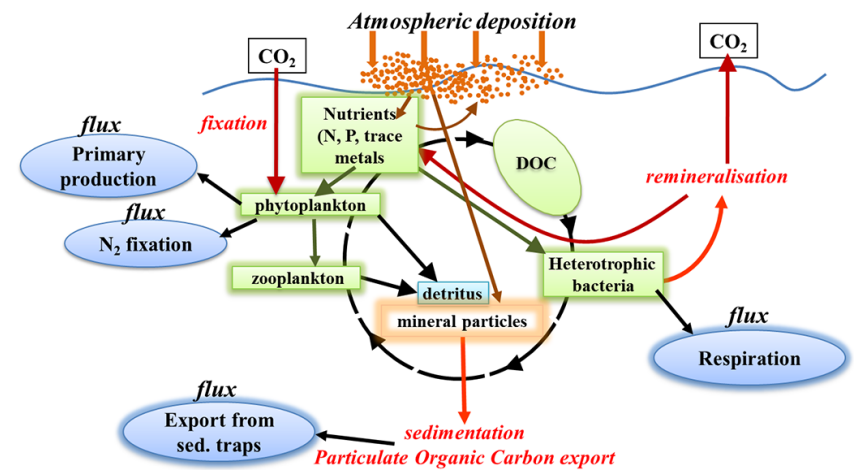

Fig. 2. Stocks (green) and fluxes (blue) measured during the DUNE experiments after the simulation of a realistic atmospheric input in a water body large enough to be representative of natural processes. As the particles are naturally sinking, those changes are closer to the "real" processes occurring in the surface mixed layer of open ocean compared to microcosm approaches where the particles are homogenized and not allowed to sink. The derived parameterizations can constrain a biogeochemical model that takes into account the atmospheric deposition in oligotrophic conditions (modified from de Leeuw et al., 2014).

Superficial soils were collected with clean plastic materials in a mineral dust source area of southern Tunisia, a region known to be a main source of mineral dust in the northwestern Mediterranean (Bergametti et al., 1989a, b). The bulk erodible soil material used to produce added dust in the DUNE experiments was collected at relatively close sites in the same dry river bed system southeast of the Chott el Djerid during two sampling campaigns in 2007 and 2009, and the dust produced has very similar characteristics. For elimination of the free sand fraction we used a $3 \mathrm{~mm}$ mesh, and the crusted clay pieces remaining were dried, crushed and sieved below $20 \mu \mathrm{m}$ in order to reproduce the mechanical action of eolian sandblasting that breaks the clay aggregates to mobilize fine particles (Fig. 3). A total of more than $3 \mathrm{~kg}$ of fine mineral dust was produced. A fraction was further processed to reproduce chemical aging by cloud water processing. Dust was mixed with acidic model cloud water and evaporated in a clean room (Guieu et al., 2010b). Sulfuric, nitric and oxalic acids were used to simulate air masses under anthropogenic influence that encounter Saharan air masses in frontal situations typical of dust transport over the Mediterranean (Moulin et al., 1998). The so-called evapocondensed dust (EC dust) and original dust (non-EC dust) fractions were used to simulate wet and dry deposition, respectively. The size distribution of both fractions was quite similar, with a particle number distribution peak at $\sim 0.10 \mu \mathrm{m}$ in diameter and a particle volume distribution peak at $\sim 10 \mu \mathrm{m}$ (Guieu et al., 2010b). The volume distribution could be fitted with three modes at about 1.6, 6.2 and $12 \mu \mathrm{m}$ that are observed to be produced by eolian erosion of arid soils (Alfaro et al., 1998). The mineralogical composition of the produced dust was found to

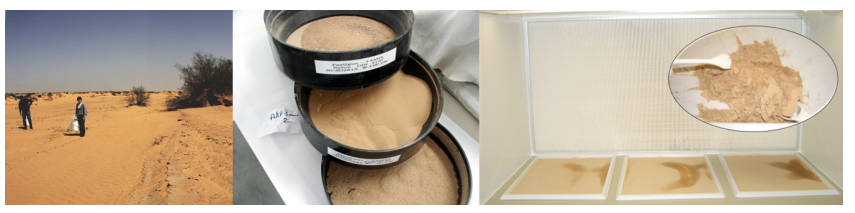

Fig. 3. The different steps of DUNE: (left panel) sampling soils in a region of southern Tunisia where Saharan aerosol is produced and is typical of inputs to the Northwestern Mediterranean. (Center panel) Soil collected in the three stages of the dry sieving column at the end of the fine-particle production process. (Right panel) Artificial aging of the atmospheric particles to mimic the wet deposition, done in a clean room to reproduce the processes taking place during aerosol transport (photos: F. Dulac, CEA; S. Tran, LISA) (taken from Guieu et al., 2010b).

be dominated by quartz $(\sim 40 \%)$, calcite $(\sim 30 \%)$ and clay ( $25 \%$ ), and the chemical composition was found to be typical of mineral dust aerosols from this region, with some enrichment in $\mathrm{Si}$ relative to $\mathrm{Al}$, but with $\mathrm{Fe}$ and $\mathrm{P}$ concentrations typical for Saharan dust. Dust processing with model cloud water resulted in a significant addition of $\mathrm{N}$ compared to initial dust (from $\sim 0.1$ to $\sim 1.4 \%$, Table 2 ), attributed to the reactivity of calcite with inorganic acids (Guieu et al., 2010b) as confirmed by a net loss of C (Table 2) that likely results from the reactivity of carbonates with inorganic acids. As discussed in further detail in Guieu et al. (2010b), the size distribution and chemical composition of both EC and nonEC dust analogs therefore appear appropriate to reproduce dry and wet deposition of mineral dust in the northwestern Mediterranean.

\subsection{Large clean mesocosms}

The second part of the methodological development concerned the actual conception of seeding experiments in large clean mesocosms. With a list of specifications (for example, those systems should be transportable and entirely consist of plastic material to avoid any contamination regarding the expected low concentrations of nutrients, etc.), the DUNE team worked on the concept of holding structures, an enclosure $\left(52 \mathrm{~m}^{3}\right)$, sampling systems and anchoring. The detailed methodological approaches have been published in Guieu et al. (2010b). The mesocosms consisted of large bags made of two $500 \mu \mathrm{m}$ thick films of polyethylene mixed with vinyl acetate (EVA, 19\%) with nylon meshing in between to allow maximum resistance and light penetration (produced by HAIKONENE KY, Finland). They were $2.3 \mathrm{~m}$ in diameter and $12.5 \mathrm{~m}$ in height for the cylindrical part, and $2.2 \mathrm{~m}$ height for the conical part at the bottom (surface is $4.15 \mathrm{~m}^{2}$ and total volume $52 \mathrm{~m}^{3}$ ). In order to preserve the structure of the surface waters and work in clean condition as much as possible while filling the bags, the bags consisted of two parts: (1) a main cylinder ( $2.3 \mathrm{~m}$ diameter) ending with a diameter tapering down to $1.5 \mathrm{~m}$ and (2) a bottom cone (Fig. 4). 
Table 2. Composition of some key elements in the dust used for seedings during DUNE.

\begin{tabular}{llll}
\hline & $\begin{array}{l}\text { Non-processed } \\
\text { representative of } \\
\text { dry deposition } \\
\text { used for DUNE-1-Q } \\
\text { exp. (1) }\end{array}$ & $\begin{array}{l}\text { Evapocondensed } \\
\text { representative of } \\
\text { wet deposition } \\
\text { used for DUNE-1-P } \\
\text { exp. (1) }\end{array}$ & $\begin{array}{l}\text { Evapocondensed } \\
\text { representative of } \\
\text { wet deposition } \\
\text { used for DUNE-2-R1 } \\
\text { and DUNE-2-R2 exp. (2) }\end{array}$ \\
\hline $\mathrm{P}(\%)$ & $0.044 \pm 0.009$ & $0.045 \pm 0.015$ & $0.055 \pm 0.003$ \\
$\mathrm{Fe}(\%)$ & $2.28 \pm 0.19$ & $2.31 \pm 0.04$ & $2.26 \pm 0.03$ \\
$\mathrm{~N}(\%)$ & $0.11 \pm 0.01$ & $1.19 \pm 0.05$ & $1.36 \pm 0.09$ \\
$\mathrm{C} \%$ & $6.75 \pm 0.01$ & $5.35 \pm 0.06$ & $5.08 \pm 0.02$ \\
\hline
\end{tabular}

(1) Guieu et al. (2010b)

(2) Desboeufs et al. (2014)

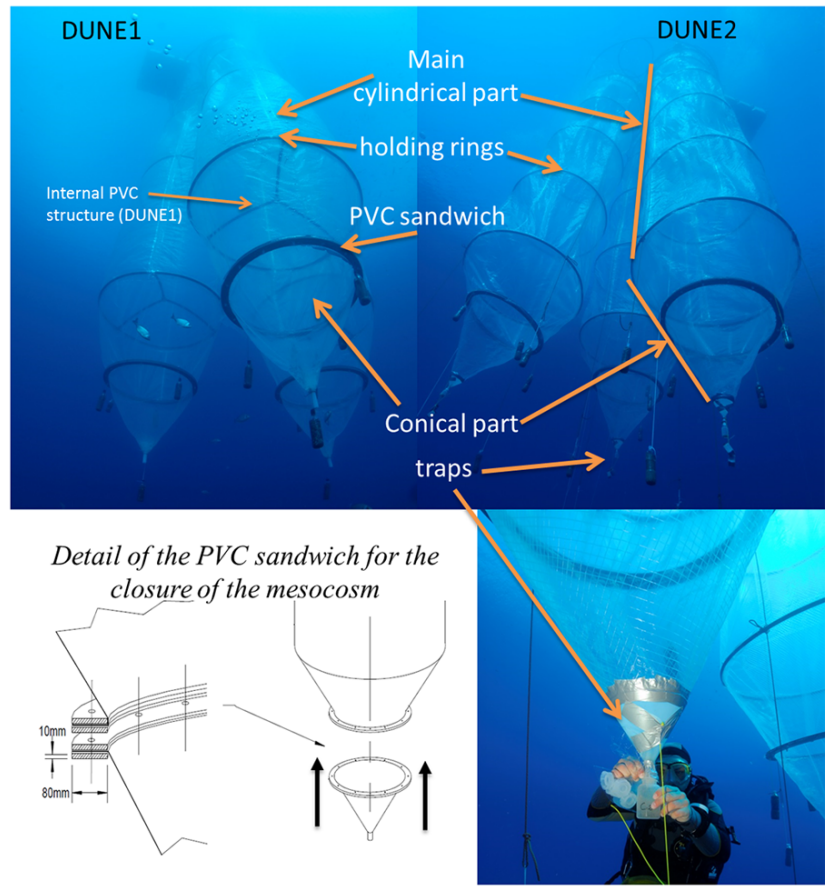

Fig. 4. Pictures of the mesocosms underwater during DUNE-1 and DUNE-2 illustrating the different aspects of the specific mesocosm design developed during DUNE. The cone at the bottom is installed underwater by two divers $24 \mathrm{~h}$ after the top piece has been deployed from the surface: the two PVC sandwiches are joined with plastic screws (photo: D. Luquet, OOV).

In order to strengthen the main cylinder and to adequately maintain the cylindrical shape for the duration of the experiment, the whole structure was rigidified thanks to large rings made from $40 \mathrm{~mm}$ diameter PE tubes: for the DUNE-1 experiment (in 2008), five such rings were installed at different levels inside horizontal tunnels of the main part of the bag and kept in place by PVC parts inside the bag. To improve the design, for DUNE-2 (in 2010), no more PVC parts were placed in the interior of the bag and instead two additional PE tube rings were put over the body of the bag (Fig. 4).
At the bottom of the main cylinder and at the top of the cone, two PVC circles ( $8 \mathrm{~cm}$ in width) were installed, thereby sandwiching the plastic (Fig. 4, bottom-left panel). The main cylindrical part of the mesocosms was deployed first: the bags, secured by three small elastic ropes, had four small ballasts temporarily attached to the PVC circle. The elastic ropes were released simultaneously, allowing the main cylinder to gently, but rapidly ( $\sim 10 \mathrm{~min}$ ), deploy vertically with the assistance of one diver, who remained away from inside areas of the bag at the level of the PVC circle. The entire operation of successively deploying the six bags took less than two hours. Once the main cylinder was deployed, it was left open for $24 \mathrm{~h}$ in order to stabilize the water mass inside. This step was also a way to remove possible particles that could have been stuck to the plastic from the time of its fabrication. After $24 \mathrm{~h}$, divers attached the conical bottom of the cylinder by screwing together (plastic screws) the two PVC sandwiches. During the entire installation, the divers followed instructions to remain away from the inside areas of the bags in order to minimize disturbance of the captured waters, particularly from air bubbles. At the base of the mesocosm, a very simple sediment trap system allowed the divers to rapidly change the traps (Fig. 4). The PE structures holding the bags, and on which the mooring was attached, were also made with PE tubes $40 \mathrm{~mm}$ in diameter) (Fig. 5). Each bag was held at several points at the level of the upper ring and at the level of the ring just below the surface of the sea: this allowed us to avoid tension being applied directly to the bags.

The structures were moored using only non-metallic material (except for the screw anchors installed at the sea floor 25$30 \mathrm{~m}$ deep). Each group of three structures was moored using three anchor screws installed $120^{\circ}$ from each other and connected to sub-surface buoys, which were themselves linked to surface buoys.

In order to exclude the possibility that a "real" deposition event could disturb the experiment, the mesocosms were covered (Fig. 5e). The cover made of transparent PVC material was designed to let the most light possible reach the body of water inside the mesocosm. Measurements of the absorption spectrum (J. Ras, personal communication, 2007) 


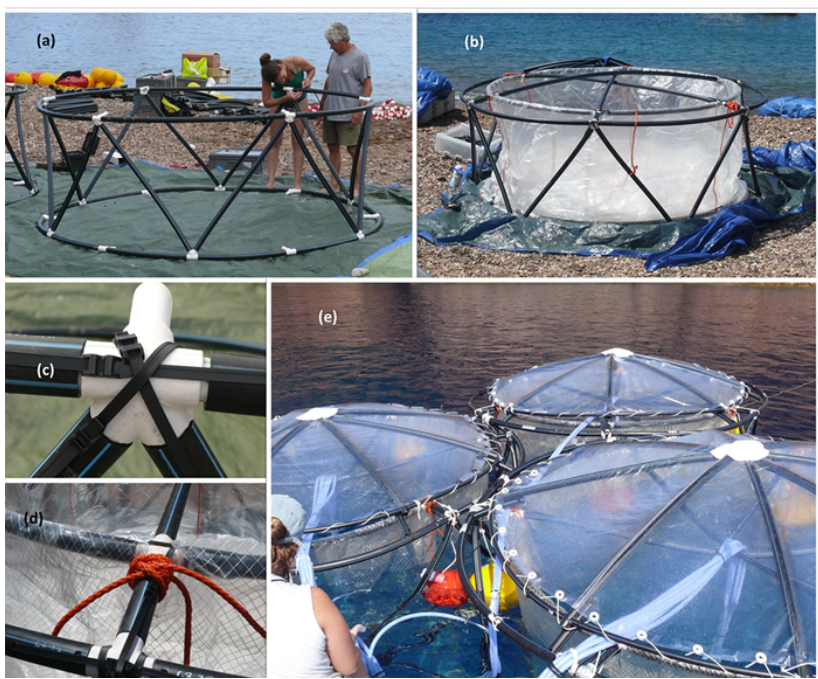

Fig. 5. Details of the mesocosm structure before (a) and after (b) installing the bag inside; (c) and (d), detailed view of the connections showing how the bag is fixed to the structure; (e) transparent covers above the bags and structures allowing the air to pass - this picture also shows the sampling tubes that allow for sampling from outside without introducing any other device into the inside of the water body (photos: DUNE Team and D. Luquet OOV).

have indicated that this PVC material absorbs light in the UV wavelengths but not in the visible wavelengths. These covers were elevated to $10 \mathrm{~cm}$ above the top of the mesocosms, allowing air to circulate so as to avoid a confinement effect in the trapped water. Indeed, comparison of the temperature measured continuously inside and outside the mesocosm showed that temperature inside the mesocosms was $3 \%$ higher than outside at maximum and $2 \%$ lower at minimum (Fig. 6).

\subsection{Seeding the mesocosm}

The dust was spread at the surface of the mesocosms using entirely plastic, $4 \mathrm{~L}$ (high-density polyethylene) sprayers (only the sprayer extension was made of a carbon tube): these devices were acid-cleaned ( $\mathrm{HCl} 5 \%)$ and rinsed thoroughly (with ultra-pure water) before use in the field. In the field, and just before the seeding, the evapocondensed dust was mixed with $2 \mathrm{~L}$ of ultra-pure water (wet deposition experiment: DUNE-1-P and DUNE-2-R), and the non-processed dust was mixed with $2 \mathrm{~L}$ of seawater (dry deposition experiment: DUNE-1-Q). Overall, the time required to prepare the dust solution and to seed the three mesocosms was $40 \mathrm{~min}$. As reported in the introduction of this paper, intense Saharan dust events can occur on very short timescales, and thus our simulation is realistic in terms of duration.

All seeding and sampling operations in the mesocosms were performed from mobile plastic platforms that were moved using several two-way ropes installed in between

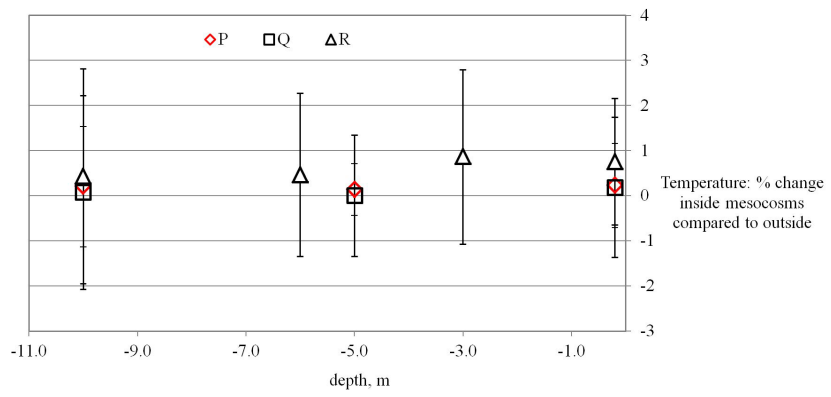

Fig. 6. Evidence of no temperature change inside the mesocosms compared to outside. The temperature was continuously monitored inside and outside the mesocosms. The percentage change $[100 \times($ temperature inside - temperature outside)/temperature outside] is reported for the depths at which the sensors were installed. Number of measurements for the three DUNE experiments (see below): $n=197$ (DUNE-P); $n=337$ (Q); $n=453$ (R).

buoys (Fig. 7). In between the two structures of three mesocosms, reference measurements were performed in free seawater (OUT). An original sampling system was designed with the goal of inducing the least possible perturbation inside the mesocosms during sampling. In each bag, three sets of clear, braided PVC tubing (Holzelock-Tricoflex, inside diameter of $9.5 \mathrm{~mm}$ ) were permanently installed at the center of the bags (Fig. 5e), with one end per each of three different depths: 10,5 and $0.1 \mathrm{~m}$. Additional depths were sampled in two of the DUST mesocosms during the DUNE-2-R experiment, as will be explained later in the document. The other ends were fixed to the outside of the mesocosms. The sampling was done by pumping: a PFA pump (St-Gobain Performance Plastics) activated by the pressurized air from a diving tank was connected successively to the ends of the tubing coming out of the mesocosm, allowing us to sample directly at the different selected depths without introducing any device into the inside of the mesocosm. This system allowed us to sample water directly, either non-filtered or filtered (using different types of cartridges according to the parameter to be measured) (Fig. 7).

In conclusion, the complete setup was a solid mooring capable of absorbing the sea swell while maintaining a supple and strong structure and ensuring that no tension was applied directly to the bags. Great precaution was taken to avoid any type of contamination (material used, designs, filling, sampling, etc.), making the DUNE mesocosm an ideal setup to study the effect of atmospheric deposition in a LNLC ecosystem. Indeed, as shown by Guieu et al. (2010b), statistical analyses on the parameters measured during DUNE-1 gave strong evidence for the representativeness of the water trapped inside the mesocosms, indicating the suitability of the applied methodology as the presence of the bag did not modify the natural biogeochemical conditions. Statistical analyses (Guieu et al., 2010b) show that data from the three DUST mesocosms that received the same treatment are 


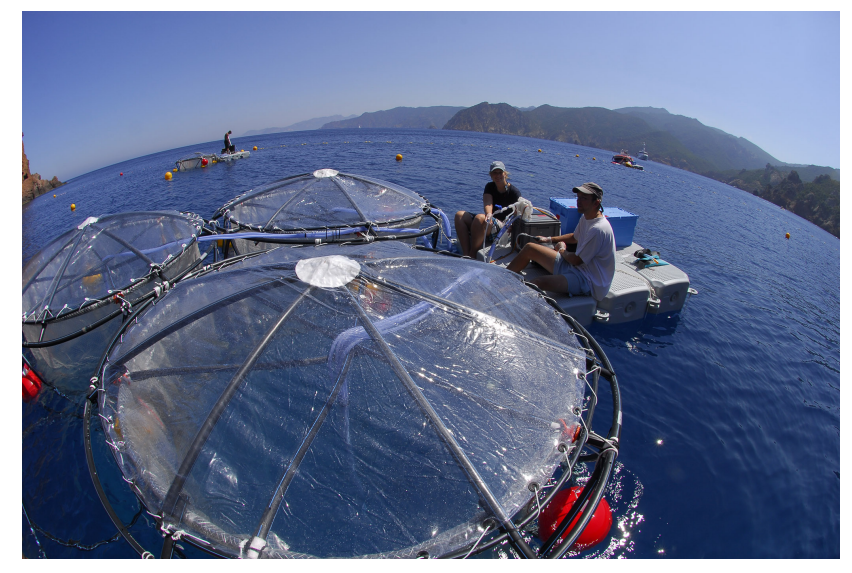

Fig. 7. Sampling the mesocosms. Each cluster of three mesocosms is simultaneously sampled a plastic platform by a team of two scientists. Overall a sampling sequence duration was less than two hours (photo: D. Luquet OOV).

highly reproducible (variation coefficient $<30 \%$ ) and that there is no significant difference between data obtained from CONTROL mesocosms and data obtained outside the mesocosms. Another very important aspect is that there was no observed chemical contamination.

\subsection{Two mesocosm experiments}

Artificial seedings over large mesocosms have been realized during two campaigns in the Scandola preservation area in Corsica: the DUNE-1 experiment in 2008 and the DUNE2 experiment in 2010. The experimental site in the Scandola preservation area - a typical LNLC area - (where the deployments took place) is also described in Guieu et al. (2010b). The implementation for the two experiments is summarized in Fig. 8.

During DUNE-1 in June 2008 we performed two distinct 8-day experiments: first, a simulation of a Saharan wet deposition event (named "DUNE-1-P"), and second, a simulation of a Saharan dry deposition event (named "DUNE-1-Q"). Mesocosms were emptied and redeployed between the two experiments; for that purpose, at the end of the first experiment, the bottom cones were unscrewed by divers, leaving the base of the mesocosms open. Thanks to lift bags installed at the base of the bags, the main cylinder could be completely lifted to the surface. This resulted in the entire volume of water trapped inside rapidly emptying out of the cylinder, while the top of the mesocosms remained attached to the holding structure. The bags were then ballasted to fill them again, and $24 \mathrm{~h}$ after this operation, the bottom cones were reattached underwater by divers. To eliminate any possibility of a memory effect between DUNE-1-P and DUNE-1-Q, the groups of seeded mesocosms were alternated. Indeed, as shown by the statistical tests in Guieu et al. (2010b), initial conditions inside and outside the mesocosms were identical.

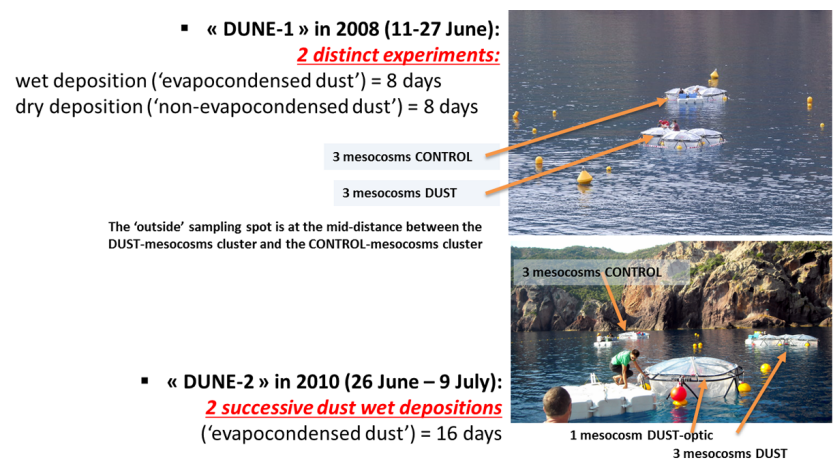

Fig. 8. Implementation of the two mesocosm experiments in the Scandola preservation area (Corsica).

DUNE-1-P and DUNE-1-Q consisted in the deployment of three mesocosms, named "CONTROL mesocosms", not subjected to any dust addition and used as a reference, and three mesocosms, hereafter named "DUST mesocosms", receiving a dust addition corresponding to a dust flux of $10 \mathrm{~g} \mathrm{~m}^{-2}$. The wet deposition event during DUNE-1-P (11-18 June 2008) was mimicked by seeding EC dust over the DUST mesocosms, and the dry deposition event during DUNE-1-Q (2027 June 2008) was mimicked by seeding non-EC dust.

During DUNE-2 in 2010 (26 June-9 July 2010): we performed a single 16-day experiment (named "DUNE-2-R") that consisted of two successive dust wet deposition simulations (using the same amount of EC dust) with 7 days between each seeding (i.e., "R1" and "R2"). DUNE-2-R consisted in the deployment of three CONTROL mesocosms (no dust addition) and four DUST mesocosms (each with dust addition corresponding to a dust flux of $10 \mathrm{~g} \mathrm{~m}^{-2}$ ), three of them being devoted to biogeochemical studies like in DUNE1-P and DUNE-1-Q, the additional mesocosm being dedicated to optical measurements. This strategy of two successive seedings was decided following DUNE-1 results. Indeed, Wagener et al. (2010) showed that dust addition during DUNE-1-P was followed by a decrease of DFe concentration likely due to DFe scavenging on settling dust particles, giving evidence that large dust deposition events may be a sink for surface ocean dissolved iron. Such an effect has also been reported for dissolved thorium (Lambert et al., 1991). Combining the mesocosm experiment with a batch dissolution experiment, Wagener et al. (2010) then showed that after biological activity was enhanced following dust addition and Fe-binding ligands have been produced, then DFe increased. Although two successive deposition events of this importance have, to our knowledge, not been reported, this strategy was planned in order to explore how dust deposition impacts biogeochemistry under different in situ biogeochemical initial conditions.

In addition, water outside of the mesocosms was sampled during the course of all the experiments for reference. 
The bulk erodible soil material used to produce added dust was collected in 2007 (and used for the DUNE-P and Q experiments) and 2009 (used for the DUNE-R experiment) for $\mathrm{R}$ experiment. The dust used during DUNE-1 and DUNE-2 had similar chemical composition for $\mathrm{P}, \mathrm{Fe}$ and $\mathrm{C}$ and was different for $\mathrm{N}$ (see Table 2 and Desboeufs et al., 2014). Indeed, the difference of one order of magnitude in the $\mathrm{N}$ content between the composition of the non-EC dust (used as a proxy for dry deposition) and the EC dust (used as a proxy for wet deposition) is due to the addition of $\mathrm{HNO}_{3}$ in the simulated cloud water used to process dust for wet deposition simulation (Guieu et al., 2010b). As shown in Ridame et al. (2014), this difference in composition regarding $\mathrm{N}$ led to very different dissolution from the two analogs, with nitrogen from the EC dust being $100 \%$ released into water almost instantaneously.

The sampling was done at the same time everyday. The schedule for sampling the mesocosm during DUNE-1 and DUNE-2 is reported in Table 3. During DUNE-1, for the discrete sampling, three depths were sampled: sub-surface, $5 \mathrm{~m}$ and $10 \mathrm{~m}$. Following the results obtained for DFe (Wagener et al., 2010), it was decided during DUNE-2 to increase the number of sampled depths for two of the DUST mesocosms and $2.5,7.5$ and $12.5 \mathrm{~m}$ depths were also sampled for trace elements. During DUNE-2, the sediment traps were changed everyday instead of every two days during DUNE-1.

\section{Main environmental initial conditions and evolution}

\subsection{Solar radiation and temperature}

Because of its weak cloud coverage, the Mediterranean Sea is subject to stronger solar radiation in comparison with oceanic areas of similar latitude (i.e., Vasilkov et al., 2001), with the consequence that the percentage of sunshine duration over the whole day is close to $100 \%$, particularly during summer. The period to perform the experiments was chosen in order to have such summer conditions with well stratified column water characterized by very poor concentration of nutrients. DUNE-1 and DUNE-2 were thus scheduled in June-July. Continuously monitored seawater temperature (see above) along with the air temperature (recorded by Météo-France at the nearby station in Calvi) are shown in Fig. 9a. The gradient between the temperature recorded at surface and $10 \mathrm{~m}$ is also presented in order to represent the thermal stratification in a first approximation (Longhurst et al., 1995) (Fig. 9b).

The seawater temperature during the $\mathrm{P}$ experiment was lower, with smaller daily amplitude than during the other experiments. Indeed, while the seawater temperature during the whole DUNE-P experiment was in the range $17-21.5^{\circ} \mathrm{C}$ and the stratification of the water column inside the mesocosms was not marked, temperature significantly increased during the following DUNE-Q experiment with a range of 18.5$26^{\circ} \mathrm{C}$. The air temperature during daytime was stable during

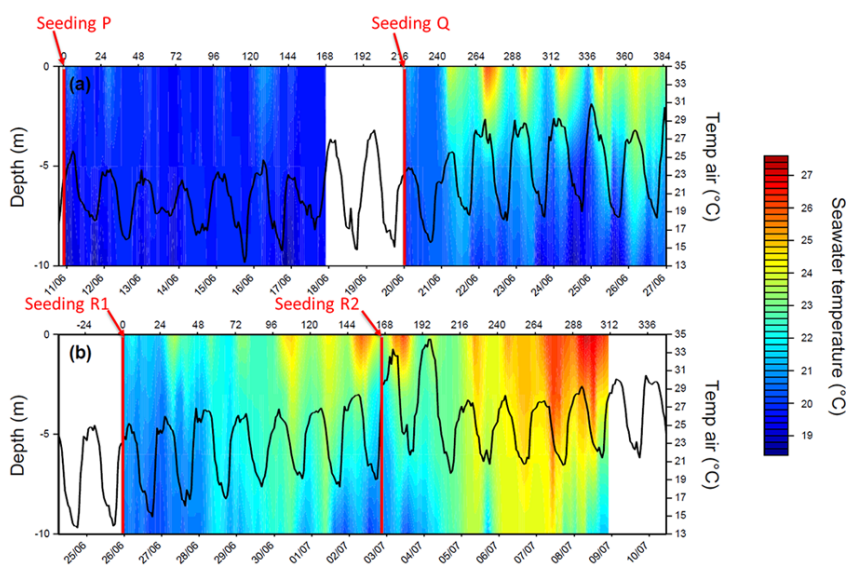

Fig. 9a. Temperature profiles inside the mesocosms during the three DUNE experiments. Air temperatures are superimposed (black line).
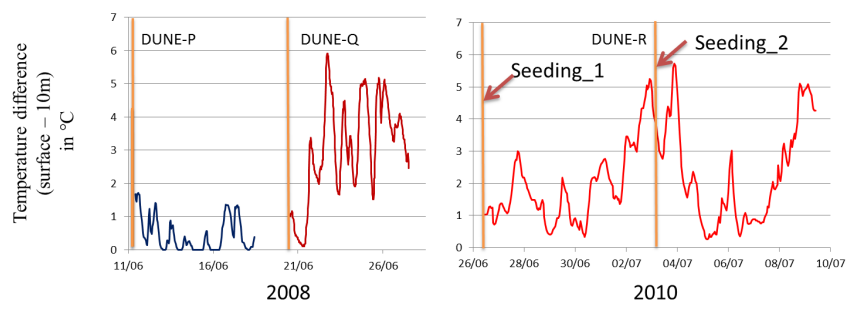

Fig. 9b. Evolution of the temperature difference between the surface and $10 \mathrm{~m}$ illustrating both the diurnal variations and the evolution of the overall stratification.

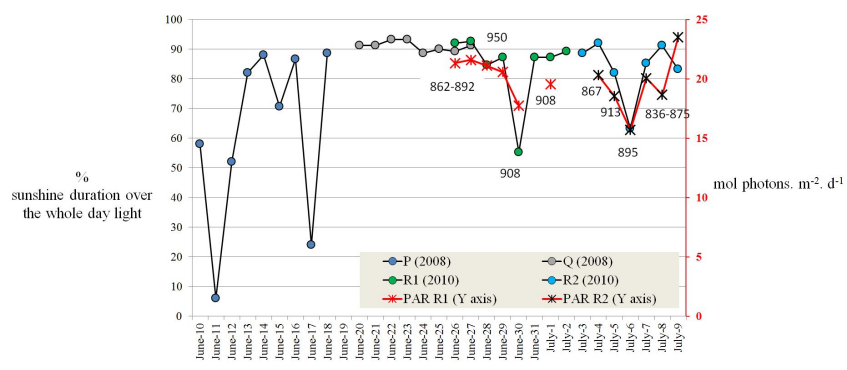

Fig. 9c. Percentage of sunshine duration over the total daytime hours ( $\sim 15 \mathrm{~h}$ in June-July) (Météo-France): PAR measurements for R1 and R2 ( $y$ axis), the integration for the whole day acquisition are presented in mol photons $\mathrm{m}^{-2} \mathrm{~d}^{-1}$ at the subsurface of the mesocosms, and the maximum flux values in $\mu$ mol photon $\mathrm{m}^{-2} \mathrm{~s}^{-1}$ are reported.

DUNE-P, with an average value of $21.7 \pm 1.8^{\circ} \mathrm{C}$, while the percentage of sunshine duration could be as low as $\sim 5$ and $\sim 25 \%$ for two days (Fig. 9c); the air temperature increased rapidly at the beginning of the DUNE-Q experiment, reaching an average value during the day of $26.3 \pm 2.6^{\circ} \mathrm{C}$ with light duration close to the maximum, typical of summer conditions in that area. This rapid increase in air temperature led to the establishment of a thermal stratification of the surface 
Table 3. Outline of sampling for all the DUNE dust seeding experiments. Sampling type OUT: all the mesocosms and a position at middistance between the two mesocosm clusters are sampled at the same depths. Sampling type IN: all the mesocosms are sampled. Time indicates the beginning of the sampling; the average total sampling time was less than two hours. Net sampling was performed at the beginning of experiments outside the mesocosms and both inside and outside after the last sampling of the experiment.

\begin{tabular}{|c|c|c|c|}
\hline Dates & $\begin{array}{l}\text { Sample } \\
\text { label }\end{array}$ & $\begin{array}{l}\text { Time } \\
\text { (local time) }\end{array}$ & Type of work \\
\hline \multicolumn{4}{|c|}{ DUNE-1-P experiment } \\
\hline June-10 & p1 & 4 p.m. & sampling type OUT + trap installation \\
\hline June-11 & - & 9 a.m. & seeding D1 D2 D3 \\
\hline June-11 & $\mathrm{p} 2$ & 4 p.m. & sampling type IN and net (1) \\
\hline June-12 & p3 & 9 a.m. & sampling type IN and traps \\
\hline June-13 & p4 & 9 a.m. & sampling type OUT \\
\hline June-14 & - & 10 a.m. & traps; no sampling of the mesocosms: bad weather conditions \\
\hline June-15 & p5 & 9 a.m. & sampling type IN \\
\hline June-16 & p6 & 9 a.m. & sampling type OUT and traps \\
\hline June-17 & p7 & 9 a.m. & sampling type IN \\
\hline June-18 & p8 & 9 a.m. & sampling type OUT, traps and nets (2) \\
\hline \multicolumn{4}{|c|}{ DUNE-1-Q experiment } \\
\hline June-19 & & 9 a.m. & trap installation \\
\hline June-20 & $\mathrm{q} 1$ & 9 a.m. & sampling type OUT \\
\hline June-20 & & 12 a.m. & seeding D1 D2 D3 \\
\hline June-20 & $\mathrm{q} 2$ & 6p.m. & sampling type IN and net (1) \\
\hline June-21 & $\mathrm{q} 3$ & 9 a.m. & sampling type IN and traps \\
\hline June-22 & $\mathrm{q} 4$ & 9 a.m. & sampling type OUT \\
\hline June-23 & q5 & 9 a.m. & sampling type IN and traps \\
\hline June-24 & q6 & 9 a.m. & sampling type IN \\
\hline June-25 & $\mathrm{q} 7$ & 9 a.m. & sampling type OUT and traps \\
\hline June-26 & q8 & 9 a.m. & sampling type IN \\
\hline June-27 & q9 & 9 a.m. & sampling type OUT, traps and nets (3) \\
\hline \multicolumn{4}{|c|}{ DUNE-2-R experiment } \\
\hline June-26 & $\mathrm{r} 1$ & 9 a.m. & sampling type OUT and net (1) \\
\hline June-26 & - & 11 a.m. & trap installation + seeding D1 D2 D3 optic \\
\hline June-26 & $\mathrm{r} 2$ & 9 p.m. & sampling type IN \\
\hline June-27 & r3 & 9 a.m. & sampling type IN and traps \\
\hline June-28 & $\mathrm{r} 4$ & 9 a.m. & sampling type OUT and traps \\
\hline June-29 & r5 & 9 a.m. & sampling type IN and traps \\
\hline June-30 & r6 & 9 a.m. & sampling type OUT and traps \\
\hline July-1 & r7 & 9 a.m. & sampling type IN and traps \\
\hline July-2 & r8 & 9 a.m. & sampling type OUT and traps \\
\hline July-3 & r9 & 9 a.m. & traps \\
\hline July-3 & - & 9 a.m. & seeding D1 D2 D3 optic \\
\hline July-3 & r9 & 2 p.m. & sampling type IN \\
\hline July-3 & r10 & 6 p.m. & sampling type IN \\
\hline July-4 & r11 & 9 a.m. & sampling type OUT and traps \\
\hline July-5 & r12 & 9 a.m. & sampling type IN and traps \\
\hline July-6 & r13 & 9 a.m. & sampling type OUT and traps \\
\hline July-7 & r14 & 9 a.m. & sampling type IN and traps \\
\hline July-8 & r15 & 9 a.m. & sampling type IN and traps \\
\hline July-9 & r16 & 9 a.m. & sampling type OUT, traps and nets (4) \\
\hline
\end{tabular}

(1) Only outside the mesocosms; (2) zooplankton sampling: "outside", C2, C3, D2, D3; (3) zooplankton sampling: "outside", C1, C2, D1, D2; (4) zooplankton sampling: "outside”, C1, C2, C3, D1, D2, D3. 
waters. The in situ data illustrate well that there was a shift during DUNE-1 from spring to summer conditions between $\mathrm{P}$ and $\mathrm{Q}$ experiments.

During DUNE-2, the seawater temperature during the whole experiment was in the range $20.0-27.3^{\circ} \mathrm{C}$, with a significant increase in surface temperature and well-stratified waters toward the ends of both seeding periods. According to seawater temperature data, the period after the R1 seeding experiment was representative of a transition between spring and summer conditions, whereas the second seeding was performed while the surface layer was well stratified. During the course of the second seeding period, a destratification followed by a restratification was observed with a strong increase in sea surface temperature typical of summer conditions. Photosynthetically available radiation (PAR) was measured both in the air and at the sub-surface of the mesocosms during DUNE-2, and even if some variation in the percentage of sunshine duration was noticed (Fig. 9c), the light flux was high during the whole experiment (Fig. 9c), with average daily flux at the sub-surface of the mesocosms of 20 and 19 mol photons $\mathrm{m}^{-2} \mathrm{~d}^{-1}$ during R1 and R2, respectively, and maxima close to $900 \mu \mathrm{mol}$ photons $\mathrm{m}^{-2} \mathrm{~s}^{-1}$. For $\mathrm{P}$ and $\mathrm{R}$ experiments, no strong and established stratification over the course of the experiment could be observed. For Q, the sharp thermocline at $\sim 5 \mathrm{~m}$ depth could have acted as a physical barrier, preventing dissolved nutrient exchange because of low diffusion between the waters above and below the thermocline but also likely preventing the export of the lithogenic particles introduced by the seeding, as the established thermocline layer acts to limit the downward transport of atmospheric material (Migon et al., 2002). Such features of the surface waters, which are well captured by the mesocosm, are important for the interpretation of biogeochemical data acquired during the experiments.

\subsection{Chlorophyll}

According to satellite data, the same type of situation regarding chlorophyll ( $\mathrm{Chl} a$ ) concentrations was encountered in 2008 and 2010 experiments: the area where the experiments took place (red circles in Fig. 10) are typical of very "blue" waters because of the uplift of the Ligurian Current along the Corsican coast that isolates the coastal area from more productive waters of the center of the Ligurian Sea: indeed, during both experiments, the tested waters were typical of oligotrophic conditions with $\mathrm{Chl} a$ concentrations in the range $0.07-0.11 \mu \mathrm{g} \mathrm{L}^{-1}$ (Table 4).

Because dust inputs to seawater have mainly been interpreted as a "fertilizer" for phytoplankton in oligotrophic systems, Chl $a$ is the parameter that has been targeted in most attempts to understand the impact of dust deposition on marine ecosystems, either considering satellite data (see, for example, Dulac et al., 1996, 2004, and Volpe et al., 2009) or microcosm experiments with dust addition (see, for example, Bon-
Table 4. Initial conditions of the tested waters during DUNE-P and DUNE-R.

\begin{tabular}{llll}
\hline & DUNE-1-P & DUNE-1-Q & DUNE-R \\
\hline $\mathrm{Chl} a\left(\mu \mathrm{g} \mathrm{L}^{-1}\right)$ & $0.11 \pm 0.03$ & $0.08 \pm 0.02$ & $0.07 \pm 0.02$ \\
$\mathrm{NO}_{3}^{-}, \mathrm{nM}$ & nd & nd & $<\mathrm{dl}^{\mathrm{a}}$ \\
$\mathrm{DIP}, \mathrm{nM}$ & $5 \pm 2^{\mathrm{b}}$ & $2 \pm 0^{\mathrm{c}}$ & $5 \pm 3^{\mathrm{d}}$ \\
$\mathrm{DFe}, \mathrm{nM}$ & $2.4 \pm 0.3^{\mathrm{e}}$ & $2.3 \pm 0.3^{\mathrm{f}}$ & $3.3 \pm 0.8^{\mathrm{g}}$ \\
\hline
\end{tabular}

${ }^{\mathrm{a}}$ Ridame et al. (2014), ${ }^{\mathrm{b}}$ Pulido-Villena et al. (2010), ${ }^{\mathrm{c}}$ Pulido-Villena (personal communication, 2013), ${ }^{\mathrm{d}}$ Pulido-Villena et al. (2014), ${ }^{\mathrm{e}}$ Wagener et al. (2010),

${ }^{\mathrm{f}}$ Wagener et al. (personal communication, 2013), ${ }^{\mathrm{g}}$ Wuttig et al. (2013), nd: non determined.

net et al., 2005). At least a doubling of Chl $a$ was observed after the DUNE-P and DUNE-R1 seedings (Fig. 11).

The second dust addition during DUNE-2 (R2) stimulated an additional $\mathrm{Chl} a$ increase (up to $+160 \%$ compared to CONTROL-MESO). Interestingly, no significant Chl $a$ increase was observed after deposition of non-EC dust (DUNE-Q). In spite of significant increase observed for DUNE-P and DUNE-R, the Chl $a$ concentrations remained low (maximum values $0.22 \mu \mathrm{g} \mathrm{L}^{-1}$ ), maintaining the oligotrophic status of the tested waters.

\subsection{Nutrients}

DIP and DFe concentrations were measured along all experiments and data for these in regard to DUNE-1-P have been reported by Pulido-Villena et al. (2010) and Wagener et al. (2010), respectively. Initial conditions for DIP indicate low and similar concentrations for all $\mathrm{P}, \mathrm{Q}$ and $\mathrm{R}$ experiments (averages 2 to $5 \mathrm{nM}$ ) (Table 4). DFe concentrations were on the same order of magnitude as DIP. Initial total DFe concentrations were similar for P and Q: respectively $2.4 \pm 0.3$ (Wagener et al., 2010) and $2.3 \pm 0.3 \mathrm{nM}$ (Wagener, personal communication, 2013) and higher for $\mathrm{R}(3.3 \pm 0.8 \mathrm{nM}$; Wuttig et al, 2013). Such nanomolar concentrations of DFe are quite typical of a coastal area (Johnson et al., 1997); for example they are on the same order of magnitude as those recently measured at $5 \mathrm{~m}$ depth in the Villefranche Bay (3.7, 3.6, and 3.8 nM in May, October, and February, respectively; Bressac and Guieu, 2014a). Initial DIN concentrations were not measured due to analytical issues during DUNE-P and Q, and were found below the detection limit $(<30 \mathrm{nM}$; Ridame et al., 2013) for DUNE-R. According to our analysis during DUNE-R, as well as to other recent measurements performed using a nanomolar technique in a similar environment in summer at the STARESO station (http://www.stareso.com) near Calvi in northwestern Corsica within the framework of the EU project MedSeA (http://medsea-project.eu) $\left(\mathrm{NO}_{3}^{-}=\right.$ $18 \pm 3 \mathrm{nM}$; J. Louis, personal communication, 2013), we can assume that the initial $\mathrm{NO}_{3}^{-}$concentrations were below $30 \mathrm{nM}$ also for $\mathrm{P}$ and $\mathrm{Q}$ experiments, in agreement with the concentrations typical of oligotrophic Mediterranean waters 

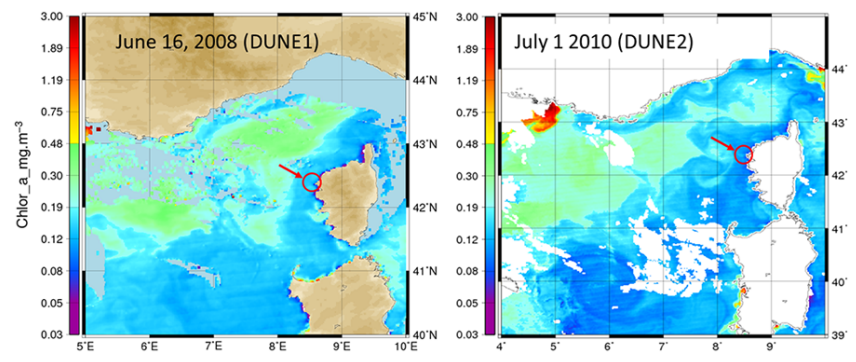

Fig. 10. MODIS satellite images showing the distribution of the surface chlorophyll $a$ at the time of DUNE-1 (left) and DUNE-2 (right). The red circle and arrow indicate the position of the experiment.

measured at that time of the year (see, for example, Pujo-Pay et al., 2011).

These data indicate overall that relatively similar in situ characteristics were encountered at the beginning of each of the three experiments DUNE-1-P, DUNE-1-Q and DUNE-2$R$. These characteristics do confirm the oligotrophic character of the experimental site. The perturbations induced by the simulated dust wet deposition (DUNE-P) or dry deposition (DUNE-Q) or two successive wet deposition (DUNE-R) can thus be (1) compared to each other and (2) taken as representative of actual changes that take place in the Mediterranean Sea (MERMEX Group, 2011). Moreover, as previously emphasized in Guieu et al. (2010b), such nanomolar concentrations of nutrients imply a specific care taken at all the different experimental steps (building, deployment, mooring, filling, seeding, sampling, chemical analysis, etc.) in order to avoid any type of contamination while using mesocosms. It is thus important to make it clear that initial conditions (Table 4) both inside and outside the mesocosms and were not significantly different $(p>0.05$ for $\mathrm{P}, \mathrm{Q}$, Guieu et al., 2010). Our methodology indeed allowed working in those delicate conditions providing for the first time a large panel of solid/reliable biogeochemical data including trace elements.

\section{Illustration of results}

In the following we illustrate results described in the DUNE special issue. Our "large clean mesocosm" approach allowed us to follow, as a function of time and taking into account the vertical dimension, a number of key parameters involved when a strong atmospheric deposition event impacts the sea surface. Chemical and biological changes in the mesocosms and in the material exported below the surface layer, along with modifications of the dynamics of particles following a wet or dry or two successive wet dust deposition events, have been followed thanks to the three experiments conducted. The multidisciplinary results described in this special issue are bringing new insights regarding the role of atmospheric

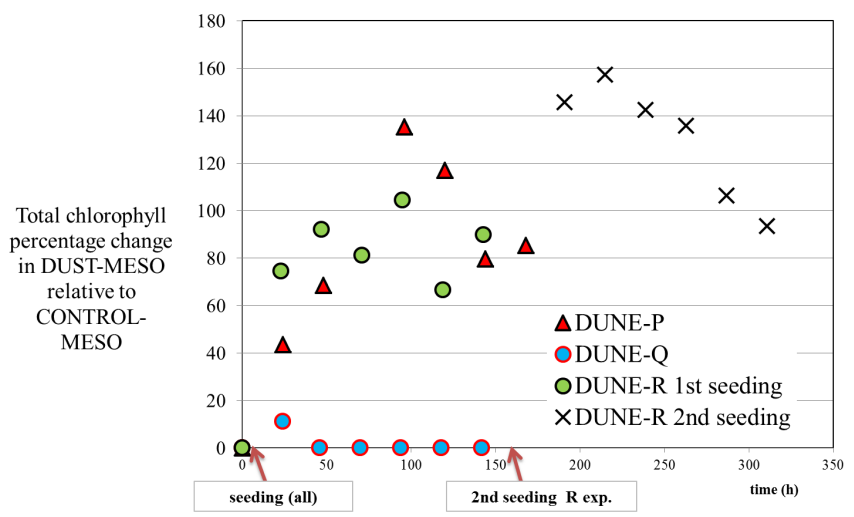

Fig. 11. Comparison of the changes in chlorophyll $a$ (relative difference between average DUST and average CONTROL mesocosms, mean of concentrations at 0,5 and $10 \mathrm{~m}$ ) observed in $\mathrm{P}, \mathrm{Q}$ and $\mathrm{R}$ experiments as a function of time after each seeding.

deposition on oligotrophic biogeochemistry, ecosystem and carbon export.

Because DUNE was a transdisciplinary project between scientists from the fields of atmospheric and oceanic sciences, an important focus of the project was to study the adsorption/desorption/dissolution processes before and after the deposition. In their paper, Aghnatios et al. (2014) report on the solubility of atmospheric nutrients from experiments conducted in the laboratory using the fine fraction of soils including the one used for the artificial seeding during DUNE. The solubility of major and trace elements was shown to mainly depend on the chemical composition - in particular on the calcium carbonate content - and on $\mathrm{pH}$ conditions.

The temporal changes in the biogeochemistry of crustal metals in the water column following dust events have been explored by Wagener et al. (2010) and Ye et al. (2011) during DUNE-1 and by Wuttig et al. (2013) during DUNE-2. The dissolved trace metals such as $\mathrm{Mn}, \mathrm{Al}$ and $\mathrm{Fe}$ showed different behavior. In the case of $\mathrm{Mn}$ and $\mathrm{Al}$, a clear increase in dissolved concentration was observed directly after both seeding R1 and R2 due to dissolution processes. However, the first seeding (R1) resulted in a decrease of DFe due to scavenging on sinking dust particles, in agreement with what was observed and modeled during DUNE1-P (Wagener et al., 2010; Ye et al., 2011), whereas the second seeding (R2) induced dissolution of $\mathrm{Fe}$ from the dust particles due to the excess Fe-binding ligand concentrations measured following the first seeding (Wuttig et al., 2013).

A number of particulate tracers were followed in the water column and in the sediment traps during the three experiments. When comparing the dust deposited with the particles in the mesocosms and those transiting below (sediment trap), Desboeufs et al. (2014) have shown that the dust composition evolves after seeding by total dissolution of calcium nitrate and calcium sulfate, which have been formed in the dust by evapocondensation processing, providing a large source of 
new nitrogen (nitrate) in the surface waters. In spite of this dissolution, the typical inter-elemental ratio, such as $\mathrm{Ti} / \mathrm{Al}$ or $\mathrm{Ba} / \mathrm{Al}$, are not affected during the dust settling, confirming their values as proxies of lithogenic fluxes or of productivity in sediment traps. A clear difference of dust settling and lithogenic material export is observed for the experiment DUNE-Q in comparison with the experiments DUNE-P and DUNE-R. Even if the stratification conditions were different for DUNE-Q, the preferential settling observed for the experiments simulating wet deposition of dust seems to be associated with biota response to the seeding. This conclusion supports the ballast effect of organic matter proposed by Bressac et al. (2014).

Wet deposition during DUNE-1-P yielded a transient increase of DIP followed by a very rapid return to initial conditions (Pulido-Villena et al., 2010). The same was observed during DUNE-2 after the first dust pulse. The second dust input also induced an increase in DIP concentration, although no return to initial conditions was observed (Pulido-Villena et al., 2014). Also during DUNE-R, both simulated wet deposition events induced a strong increase in nitrate concentration (up to $\sim 10 \mu \mathrm{M}$ at the surface) (Ridame et al., 2014). By transiently increasing DIP and DIN concentrations in Pand N-starved surface waters of the Mediterranean Sea, wet deposition of Saharan dust can likely relieve the potential P and/or N limitation of biological activity. Those results have all clearly shown the potential for Saharan wet deposition to modify the in situ concentrations of elements of biogeochemical interest such as $\mathrm{Fe}, \mathrm{P}$ and $\mathrm{N}$. An important focus of DUNE was to quantify the impact in terms of biological response. Wet deposition of dust strongly stimulated primary production (PP), and this during several days, indicating that dust was able to relieve the ambient nutrient limitation(s) of PP. Based on the new production (NP) estimates, a switch from a regenerated-production-based system $(\mathrm{NP} \sim 15 \% \mathrm{PP})$ to a new-production-based system (NP $65 \% \mathrm{PP})$ is evidenced $24 \mathrm{~h}$ after P and R seedings (Ridame et al., 2014). This new production was supported by different size class organisms depending on conditions. Indeed, Giovagnetti et al. (2013) showed that during DUNE-R small phytoplankton $(<3 \mu \mathrm{m})$ was better stimulated after the first dust addition (R1), whereas the larger size class $(>3 \mu \mathrm{m})$ significantly increased after the second addition (R2). The regulation of photobiological processes was distinctively affected by nutrient availability in both phytoplanktonic size classes. Picophytoplankton is the first group responding to dust additions in terms of both ecophysiological state of cells and community composition. However, larger-sized cells need further nutrient supply in order to be able to adjust their physiology and compete for resource acquisition and biomass increase. Among microorganisms responding to the atmospheric inputs, a specific focus was put on abundance, diversity and $\mathrm{N}_{2}$-fixing activity of diazotrophs following dry and wet deposition. Ridame et al. (2013) show that $\mathrm{N}_{2}$ fixation, although only responsible for a few percent of the induced new pro- duction, is strongly stimulated by both wet and dry atmospheric deposition. The response of the picoplanktonic unicellular diazotrophic cyanobacteria (UCYN), which dominate the community of diazotrophic cyanobacteria over the Mediterranean Sea (Le Moal et al., 2011), was more contrasted. Dry deposition (Q experiment.) led to a strong increase in the UCYN abundance, while simulated wet events induced a slight increase in UCYN during DUNE-R and no response over DUNE-P (I. Biegala, personal communication, 2013). Changes in bacterial community structure have been evidenced during DUNE-1 as Saharan dust was shown to induce changes in the active community of particle-attached bacteria as a higher contribution of Alteromonas macleodii to the active bacterial community was found at the end of the experiment (Laghdass et al., 2011). The authors hypothesized that small dust particles, by providing a source of $\mathrm{Fe}$, might favor the activity of specific heterotrophic bacteria like A. macleodii due to siderophore production. Similarly, during DUNE-2, dust deposition modified bacterial community structure by selectively stimulating and inhibiting certain members of the bacterial community. These modifications, however, did not translate into changes in bacterial diversity, which remained constant over the duration of the experiment (Pulido-Villena et al., 2014). The microbial food web dynamics were strongly impacted by dust deposition, as shown by Pulido-Villena et al. (2014). The first dust pulse in DUNE2 stimulated bacterial activity (i.e., respiration processes) more than abundance and/or community structure. This pronounced stimulation of bacterial respiration appeared to be bottom-up-controlled after the first dust pulse R1. The second dust pulse (R2) enhanced viral production, which may have top-down-controlled bacterial activity during the second part of $\mathrm{R} 2$. The observed rapid $\mathrm{C}$ remineralization due to microbial food web processes may question the nature of the link between dust deposition and carbon cycling, which may not directly involve an increase in $\mathrm{CO}_{2}$ sequestration by the ocean. Indeed, the tested waters during DUNE-1 and DUNE-2 were representative of the oligotrophic Mediterranean Sea, i.e., characterized by a strong net heterotrophy (i.e., ratio of net primary production to bacteria respiration $<1$ ) (Guieu et al., 2014a). The carbon budget indicates that the net heterotrophy character remained (or was even increased) after the dust addition despite the significant stimulation of autotrophs. This indicates that the atmospheric input does not have a simple fertilization effect, as one could have concluded from studies where the carbon budget was not possible to quantify. The view that atmospheric deposition does not just result in a simple, universal fertilization effect on phytoplankton and that heterotrophic processes may be more stimulated than autotrophic ones, was also shared by Maranon et al. (2010) for the Atlantic Ocean. Our numbers indeed indicate that the system is a net $\mathrm{CO}_{2}$ source after dust deposition. Nonetheless, the system was able to export organic material, likely thanks to sufficient DOC stock in the surface waters: the importance of aggregation processes 
between organic material and dust was evidenced by a series of optical measurements performed inside one seeded mesocosm during DUNE-2 (Bressac et al., 2012). A clear link has been established between the lithogenic fluxes and the POC fluxes as (1) the lithogenic fluxes explained more than $80 \%$ of the variance in the POC fluxes (Bressac et al., 2014; Desboeufs et al., 2014), and (2) 42-50\% of the POC flux was strictly associated with lithogenic particles through aggregation (Bressac et al., 2014). These observations support the "ballast" hypothesis and suggest that this "lithogenic carbon pump" could represent a major contribution of the global carbon export in areas receiving high rates of atmospheric deposition.

In parallel, we used a stoichiometric microbial food web model to investigate how ecological stoichiometric mismatches within the food web - that is, resources and consumers have distinct elemental composition - result in differential consumer-driven nutrient recycling (CNR; Sterner and Elser, 2002) and how, in turn, CNR feedbacks on the magnitude of the ecosystem respond to the addition of nutrients from dust (Pondaven et al., 2014). This model was used as a theoretical tool; that is, it was not optimized to fit observations from DUNE experiments. However, observations were used to constrain key model parameters (e.g., total amount of nutrient available in the system before nutrient addition) and to evaluate the overall reliability of the transient model behavior after an instance of nutrient addition mimicking the observed input from dusts. All other things being equal, the model suggested that stoichiometric mismatch along the food chain induced substantial variations in the biomass of all biological compartments (for example, total POC ranged from 3.5 to $8.5 \mathrm{mg} \mathrm{C} \mathrm{m}^{-3}$ ), as well as variations in primary production and respiration of the whole community (from 1.5 to $5.5 \mathrm{mg} \mathrm{C} \mathrm{m}^{-3} \mathrm{~d}^{-1}$, and from 1.5 to $6.5 \mathrm{mg} \mathrm{C} \mathrm{m}^{-3} \mathrm{~d}^{-1}$, respectively). Higher biomass and PP rates, and lower respiration rates, were predicted when resources had lower $\mathrm{C}: \mathrm{P}$ or $\mathrm{N}: \mathrm{P}$ elemental ratios than their consumers, meaning that $\mathrm{P}$ was in excess in the resource compared to the consumer's requirement. This led to higher rates of $\mathrm{P}$ recycling, which fueled the mostly P-limited primary production; that is, predicted PP was strongly correlated with $\mathrm{P}$ recycling rates $\left(\mathrm{nM} \mathrm{Pd}{ }^{-1}\right)\left(r^{2} \sim 0.70, p<0.001\right)$, and only moderately correlated with $\mathrm{N}$ recycling $\left(\mathrm{nM} \mathrm{N} \mathrm{d}^{-1}\right)\left(r^{2} \sim 0.10, p<0.001\right)$. Additionally, the model suggested that bacteria were the major contributors to the supply rate of $\mathrm{P}$ in the dissolved pools. This contribution was triggered by the strength of the stoichiometric mismatch between the resource (dissolved organic matter) and bacteria. Although the model was kept simple, it highlights how stoichiometric mismatch between producers and consumers can influence the response of a planktonic food web to nutrient addition (Pondaven et al., 2014).

Results from the DUNE project have shown well that the atmospheric input result is not a simple fertilization effect. Taking into account the vertical dimension in studies on the impact of atmospheric deposition in seawater is absolutely necessary. In doing so, it also permitted showing how difficult respective effects of biotic and abiotic processes are to distinguish, and thus new developments are ongoing to strictly quantify both (Bressac and Guieu, 2013).

Acknowledgements. The DUNE project, a DUst experiment in a low Nutrient, low chlorophyll Ecosystem, is a fundamental research project funded by the ANR under the contract ANR07-BLAN-0126-01. It was conducted in partnership with the laboratory of LISA (Créteil), LEMAR (Brest) and LOCEAN (Paris), and in collaboration with the laboratories LOMIC (Banyuls), IRD/LOBP/COM (Marseille), CEFREM (Perpignan), CERES/ERTI, ENS (Paris) and the Parc Naturel Régional Corse, Scandola preservation area. DUNE was also conducted in strong collaboration with foreign research institutes, including the Institut des Régions Arides (IRA), Médenine (Tunisia); IFMGEOMAR, Kiel (Germany); Stazione Zoologica Anton Dohrn, Napoli (Italy); and the Alfred Wegener Institute, Bremerhaven (Germany). This work would not have been possible without the huge involvement of engineers F. Louis and J. M. Grisoni as well as divers J. M. Grisoni, D. Luquet, M. C. Rouvières and L. Gilleta from the Observatoire Océanologique de Villefranchesur-Mer. DUNE was endorsed by the international SOLAS (Surface Ocean - Lower Atmosphere) program in February 2009 (http://www.solas-int.org/activities/project-endorsement.html).

The authors wish to thank the two anonymous reviewers and M. D. Loÿe-Pilot for their helpful comments in the discussion version of the paper.

Edited by: E. Marañón

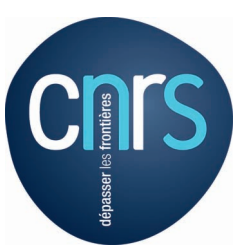

The publication of this article is financed by CNRS-INSU.

\section{References}

Aghnatios, C., Losno, R., and Dulac, F.: A fine fraction of soil used as an aerosol analogue during the DUNE experiment: sequential solubility in water with step-by-step decreasing $\mathrm{pH}$, Biogeosciences Discuss., accepted, 2014.

Alfaro, S. C., Gaudichet, A., Gomes, L., and Maillé, M.: Mineral aerosol production by wind erosion: aerosol particle sizes and binding energies, Geophys. Res. Lett., 25, 991-994, 1998.

Andersen, V. and L. Prieur:, One-month study in the open NW Mediterranean Sea (DYNAPROC experiment, May 1995): Overview of the hydrobiogeochemical structures and effects of wind events, Deep-Sea Res. I, 47, 397-422, 2000.

Bergametti, G., Gomes, L. Remoudaki, E., Desbois, M., Martin, D., and Buat-Ménard, P.: Present, transport and deposition patterns of African dusts to the north-western Mediterranean, in: Paleoclimatology and Paleometeorology: Modern and Past Patterns of Global Atmospheric Transport, edited by: Leinen, M. and Sarnthein, M., Kluwer, 227-252, 1989a. 
Bergametti, G., Dutot, A. L., Buat-Ménard, P., Losno, R., and Remoudaki, E.: Seasonal variability of the elemental composition of atmospheric aerosol particles over the northwestern Mediterranean, Tellus B, 41, 353-361, 1989b.

Bergametti, G., Remoudaki, E., Losno, R., Steiner, E., Chatenet, B., and Buat-Ménard, P... Source, transport and deposition of atmospheric phosphorus over the northwestern Mediterranean, J. Atmos. Chem., 14, 501-513, 1992.

Blain, S., Queguiner, B., Armand, L., Belviso, S., Bombled, B., Bopp, L., Bowie, A., Brunet, C., Brussaard, C., Carlotti, F., Christaki, U., Corbiere, A., Durand, I., Ebersbach, F., Fuda, J., Garcia, N., Gerringa, L., Griffiths, B., Guigue, C., Guillerm, C., Jacquet, S., Jeandel, C., Laan, P., Lefevre, D., Lo Monaco, C., Malits, A., Mosseri, J., Obernosterer, I., Park, Y., Picheral, M., Pondaven, P., Remenyi, T., Sandroni, V., Sarthou, G., Savoye, N., Scouarnec, L., Souhaut, M., Thuiller, D., Timmermans, K., Trull, T., Uitz, J., van Beek, P., Veldhuis, M., Vincent, D., Viollier, E., Vong, L., and Wagener, T.: Effect of natural iron fertilization on carbon sequestration in the Southern Ocean, Nature, 446, 10701074, 2007.

Bonnet, S. and Guieu, C.: Atmospheric Forcing on the Annual Iron Cycle in the Mediterranean Sea. A one-year Survey, J. Geophys. Res., 111, C09010, doi:10.1029/2005JC003213, 2006.

Bonnet, S., Guieu, C., Chiaverini, J., Joséphine Ras, J., and Agnès Stock, A.: Impact of atmospheric inputs on the autotrophic communities in a low nutrient low chlorophyll system, Limnol. Oceanogr., 50, 1810-1819, 2005.

Boyd, P. W., Jickells, T., Law, C. S., Blain, S., Boyle, E. A., Buesseler, K. O., Coale, K. H., Cullen, J. J., de Barr, H. J. W., Follow, M., Harvey, M., Lancelot, C., Levasseur, M., Owens, N. P. J., Pollard, R., Rivkin, R. B., Sarmiento, J., Schoemann, V., Smetacek, V., Takeda, S., Tsuda, A., Turner, S., and Watson, A. J.: A synthesis of mesoscale iron-enrichment experiments 19932005: key findings and implications for ocean biogeochemistry, Science, 315, 612-617, 2007.

Bressac, M. and Guieu, C.: Organic complexation versus scavenging: What really happens to new atmospheric iron in the ocean surface?, Global Biogeochem. Cy., 27, 859-870, doi:10.1002/gbc.20076, 2013.

Bressac, M., Guieu, C., Doxaran, D., Bourrin, F., Obolensky, G., and Grisoni, J. M.: A mesocosm experiment coupled with optical measurements to observe the fate and sinking of atmospheric particles in clear oligotrophic waters, Geo-Mar. Lett., 32, 153164, 2012.

Bressac, M., Guieu, C., Doxaran, D., Bourrin, F., Desboeufs, K., Leblond, N., and Ridame, C.: Quantification of the lithogenic carbon pump following a dust deposition event, Biogeosciences, in press, 2014.

Davies, J. and Buat-Ménard, P.: Impact of atmospheric deposition on particulate manganese and aluminium distribution in northwestern Mediterranean surface water, Paleaogeogr. Palaeocl., 89, 35-45, doi:10.1016/0031-0182(90)90050-H, 1990.

de Baar, H. J. W., Boyd, P. W., Coale, K. H., Landry, M. R., Tsuda, A., Assmy, P., Bakker, D. C. E., Bozec, Y., Barber, R. T., Brzezinski, M. A., Buesseler, K. O., Boyé, M., Croot, P. L., Gervais, F., Gorbunov, M. Y., Harrison, P. J., Hiscock, W. T., Laan, P., Lancelot, C., Law, C. S., Levasseur, M., Marchetti, A., Millero, F. J., Nishioka, J., Nojiri, Y.. van Oijen, T. Riebesell, U., Rijkenberg, M. J. A., Saito, H., Takeda, S., Timmer- mans K. R., Veldhuis, M. J. W., Waite, A. M., and Wong, C.S.: Synthesis of iron fertilization experiments: From the Iron Age in the Age of Enlightenment, J. Geoph. Res., 110, C09S16, doi:10.1029/2004JC002601, 2005.

de Leeuw, G., Guieu, C., Arneth, A., Bellouin, N., Bopp, L., Boyd, P., Denier van der Gon, H., Desboeufs, K., Dulac, F., Facchini, C., Gantt, B., Langmann, B., Mahowald, N., Maranon, E., O'Dowd, C., Olgun, N., Pulido-Villena, E., Rinaldi, M., Stephanou, E., Wagener, T.: Ocean-Atmosphere interactions of particles, in: Ocean-Atmosphere Interactions of Gases and Particles, edited by: Liss, P. and Johnson, M., Publisher, Springer, Springer Berlin Heidelberg, 171-246, 2014.

Desboeufs, K. V., Leblond, N., Wagener, T., Bon Nguyen, E., and Guieu, C.: Chemical fate and settling of mineral dust after atmospheric deposition observed from dust seeding experiments in large mesocosms, Biogeosciences, submitted, 2014.

D’Ortenzio, F., Iudicone, D., de Boyer Montégut, C., Testor, P., Antoine, D., Marullo, S., Santoleri, R., and Madec, G.: Seasonal variability of the mixed layer depth in the Mediterranean Sea as derived from in situ profiles, Geophys. Res. Lett., 32, L12605, doi:10.1029/2005GL022463, 2005.

Duce, R. A., Liss, P. S., Merill, J. T., Atlas, E. L., Buat-Menard, P., Hicks, B. B., Miller, J. M., Prospero, J. M., Arimoto, R., Church, T. M., Ellis, W., Galloway, J. N., Hansen, L., Jickells, T. D., Knap, A. H., Reinhardt, K. H., Schneider, B. Soudine, A., Tokos, J. J., Tsunogai, S., Wollast, R., and Zhou, M.: The atmospheric input of trace species to the world ocean, Global Biogeochem. Cy., 5, 193-259, doi:10.1029/91GB01778, 1991.

Dulac, F., Moulin, C., Lambert, C. E., Guillard, F., Poitou, J., Guelle, W., Quétel, C. R., Schneider, X., and Ezat, U.: Quantitative remote sensing of African dust transport to the Mediterranean, in:The Impact of Desert Dust Across the Mediterranean, edited by: Guerzoni, S. and Chester, R., Kluwer, 25-49, 1996.

Dulac, F., Moulin, C., Planquette, H., Schulz, M., and Tartar, M.: African dust deposition and ocean colour in the eastern Mediterranean, Rapp. Comm. Int. Mer Médit, Commission Internationale pour l'Exploration Scientifique de la Méditerranée, Monaco, 37, 190, 2004.

Emerson, S., Quay, P., Karl, D., Winn, C., Tupas, L., and Landry, M.: Experimental determination of the organic carbon flux from open-ocean surface waters, Nature, 389, 951-954, 1997.

Giorgi, F.: Climate change hot-spots, Geophys. Res. Lett. 33, L08707, doi:10.1029/2006GL025734, 2006.

Giovagnetti, V., Brunet, C., Conversano, F., Tramontano, F., Obernosterer, I., Ridame, C., and Guieu, C.: Assessing the role of dust deposition on phytoplankton ecophysiology and succession in a low-nutrient low-chlorophyll ecosystem: a mesocosm experiment in the Mediterranean Sea, Biogeosciences, 10, 2973-2991, doi:10.5194/bg-10-2973-2013, 2013.

Guerzoni, S., Chester, R., Dulac, F., Herut, B., Loÿe-Pilot, M. D., Measures, C., Migon, C., Molinaroli, E., Moulin, C., Rossini, P., Saydam, C., Soudine, A., and Ziveri, P.: The role of atmospheric deposition in the biogeochemistry of the Mediterranean Sea, Progr. Oceanogr., 44, 147-190, 1999.

Guieu, C., Bozec, Y., Blain, S., Ridame, C., Sarthou, G., and Leblond, N.:, Impact of high Saharan dust inputs on dissolved iron concentrations in the Mediterranean Sea, Geophys. Res. Lett., doi:10.1029/2001GL014454, 2002. 
Guieu, C., Bonnet, S., Wagener, T., and Loÿe-Pilot, M.-D.: Biomass burning as a source of dissolved iron to the open ocean?, Geophys. Res. Lett., 32, L19608, doi:10.1029/2005GL022962, 2005.

Guieu, C., Loÿe-Pilot, M-D, Benyaya, L., and Dufour, A.: Spatial and temporal variability of atmospheric fluxes of metals (Al, Fe, $\mathrm{Cd}, \mathrm{Zn}$ and $\mathrm{Pb}$ ) and phosphorus over the whole Mediterranean from a one-year monitoring experiment; biogeochemical implications, Mar. Chem., 120, 164-178, 2010a.

Guieu, C., Dulac, F., Desboeufs, K., Wagener, T., Pulido-Villena, E., Grisoni, J.-M., Louis, F., Ridame, C., Blain, S., Brunet, C., Bon Nguyen, E., Tran, S., Labiadh, M., and Dominici, J.-M.: Large clean mesocosms and simulated dust deposition: a new methodology to investigate responses of marine oligotrophic ecosystems to atmospheric inputs, Biogeosciences, 7, 27652784, doi:10.5194/bg-7-2765-2010, 2010b.

Guieu, C., Ridame, C., Pulido-Villena, E., Bressac, M., Desboeufs, K., and Dulac, F.: Dust deposition over oligotrophic marine environment: impact on carbon budget, Biogeosciences Discuss., in press, 2014a.

Guieu, C., Aumont, O., Paytan, A., Bopp, ,L. Law, C. S., Mahowald, N., Achterberg, E. P., Marañón, E., Salihoglu, B., Crise, A., Wagener, T., Herut, B., Desboeufs, K., Kanakidou, M., Olgun, N., Peters, F., Pulido-Villena, E., Tovar-Sanchez, A., and Völker, C: Significant biological responses to pulsed atmospheric deposition in Low Nitrate Low Chlorophyll regions of the ocean, Global Biogeochem. Cy., submitted, 2014b.

Herut, B., Krom, M. D., Pan, G., and Mortimer, R.: Atmospheric input of nitrogen and phosphorus to the Southeast Mediterranean: sources, fluxes, and possible impact, Limnol. Oceanogr., 44, 7, 1683-1692, 1999.

Jickells, T. D., An, Z. S., Andersen, K. K., Baker, A. R., Bergametti, G., Brooks, N., Cao, J. J., Boyd, P. W., Duce, R. A., Hunter, K. A., Kawahata, H., Kubilay, N., La Roche, J., Liss, P. S., Mahowald, N., Prospero, J. M., Ridgwell, A. J., Tegen, I., and Torres, R.:: Global Iron Connections Between Desert Dust, Ocean Biogeochemistry, and Climate, Science, 308, 67-71, 2005.

Johnson, K. S., Gordon, R. M., and Coale, K. H.: What controls dissolved iron in the world ocean?, Mar. Chem., 57, 137-161, 1997.

Klein, C., Dolan, J. R., and Rassoulzadegan, F.: Experimental examination of the effects of rainwater on microbial communities in the surface layer of the NW Mediterranean Sea, Mar. Ecol.Prog. Ser., 158, 41-50, 1997.

Kouvarakis, G., Mihalopoulos, N., Tselepides, A., and Stavrakakis, S.: On the importance of atmospheric inputs of inorganic nitrogen species on the productivity of the Eastern Mediterranean Sea, Global Biogeochem. Cy., 15, 805-817, doi:10.1029/2001GB001399, 2001.

Krom, M. D., Herut, B., and Mantoura, R. F. C.: Nutrient budget for the Eastern Mediterranean: implications for P limitation, Limnol. Oceanogr., 49, 1582-1592, 2004.

Laghdass, M., Blain, S., Besseling, M., Catala, P., Guieu, C., and Obernosterer, I.: Impact of Saharan dust deposition on the bacterial diversity and activity in the NW Mediterranean Sea, Aquat. Microb. Ecol., 62, 201-213, 2011.

Lambert, C. E., Fowler, S., Miquel, J. C., Buat-Ménard, P., Dulac, F., Nguyen, H. V., Schmidt, S., Reyss, J. L., and La Rosa, J.: ${ }^{234}$ Th: an ambiguous tracer of biogenic particle export from northwestern surface waters, in: Radionuclides in the Study of
Marine Processes (RADSTOMP 91), edited by: Kershaw, P. and Woodhead, D. S., Elsevier, 116-128, 1991.

Law, C. S., Brévière, E., de Leeuw, G., Garçon V., Guieu, C., Kieber, D., Kontradowitz S., Paulmier, A., Quinn, P., Saltzman, E., Stefels, J., and von Glasow, R.: Evolving Research Directions in Surface Ocean-Lower Atmosphere (SOLAS) Science, Environ. Chem., 10, 1-16, 2013.

Le Moal, M., Collin, H., and Biegala, I. C.: Intriguing diversity among diazotrophic picoplankton along a Mediterranean transect: a dominance of rhizobia, Biogeosciences, 8, 827-840, doi:10.5194/bg-8-827-2011, 2011.

Longhurst, A.: Seasonal cycles of pelagic production and consumption, Progr. Oceanogr., 36, 77-167, 1995.

Loÿe-Pilot, M.-D. and Martin, J. M.: Saharan dust input to the western Mediterranean: an eleven years record in Corsica, in: The Impact of Desert Dust Across the Mediterranean, edited by: Guerzoni, S. and Chester, R., Kluwer, 191-199, 1996.

Loÿe-Pilot, M.-D., Martin, J. M., and Morelli, J.: Influence of Saharan dust on the rain acidity and atmospheric input to the Mediterranean, Nature, 321, 427-428, doi:10.1038/321427a0, 1986.

Loÿe-Pilot, M. D., Martin, J. M., and Morelli, J.: Atmospheric input of inorganic nitrogen to the Western Mediterranean, Biogeochemistry, 9, 117-134, 1990.

Mahowald, N. M., Kloster, S., Engelstaedter, S., Moore, J. K., Mukhopadhyay, S., McConnell, J. R., Albani, S., Doney, S. C., Bhattacharya, A., Curran, M. A. J., Flanner, M. G., Hoffman, F. M., Lawrence, D. M., Lindsay, K., Mayewski, P. A., Neff, J., Rothenberg, D., Thomas, E., Thornton, P. E., and Zender, C. S.: Observed 20th century desert dust variability: impact on climate and biogeochemistry, Atmos. Chem. Phys., 10, 10875-10893, doi:10.5194/acp-10-10875-2010, 2010.

Marañón, E., Fernández, A., Mouriño-Carballido, B., MartínezGarcía, S., Teira, E., Cermeño, P., Chouciño, P., Huete-Ortega, M., Fernández, E., Calvo-Díaz, A., Morán, X. A. G., Bode, A., Moreno-Ostos, E., Varela, M. M., D. Patey, M. D., and Achterberg, E. P.: Degree of oligotrophy controls the response of microbial plankton to Saharan dust, Limnol. Oceanogr., 55 2339-2352, 2010.

Markaki, Z., Oikonomou, K., Kocak, M., Kouvarakis, G., Chaniotaki, A., Kubilay, N., and Mihalopoulos, N.: Atmospheric deposition of inorganic phosphorus in the Levantine Basin, eastern Mediterranean: spatial, temporal variability and its role on the productivity of the eastern Mediterranean Sea, Limnol. Oceanogr., 48, 1557-1568, 2003.

Markaki, Z., Loÿe-Pilot, M. D., Violaki, K., Benyahya, L., and Mihalopoulos, N.: Variability of atmospheric deposition of dissolved nitrogen and phosphorus in the Mediterranean and possible link to the anomalous seawater N/P ratio, Mar. Chem., 120, 187-194, 2010.

Martin, J. H., Coale, K. H., Johnson, K. S.,, et al.: Testing the iron hypothesis in ecosystems of the equatorial Pacific Ocean, Nature, 371, 123-129, 1994.

MERMEX group: Marine Ecosystems Responses to climatic and anthropogenic forcings in the Mediterranean, Progr. Oceanogr., 91, 97-166, 2011.

Migon, C. and Sandroni, V.: Phosphorus in rainwater: partitioning inputs and impact on the surface coastal ocean, Limnol. Oceanogr., 44, 1160-1165, 1999. 
Migon, C., Morelli, J., Nicolas, E., and Copin-Montegut, G.: Evaluation of total atmospheric deposition of $\mathrm{Pb}, \mathrm{Cd}, \mathrm{Cu}$ and $\mathrm{Zn}$ to the Ligurian Sea, Sci. Total Environ., 105, 135-148, 1991.

Migon, C., Sandroni, V., Marty, J. C., Gasser, B., and Miquel, J. C.: Transfer of atmospheric matter through the euphotic layer in the northwestern Mediterranean: seasonal pattern and driving forces, Deep-Sea Res. II, 49, 2125-2141, 2002.

Moore, C. M., Mills, M. M., Arrigo, K. R., Berman-Frank, I., Bopp, L., Boyd, P. W., Galbraith, E. D., Geider, R. J., Guieu, C., Jaccard, S. L., Jickells, T. D., La Roche, J., Lenton, T., Mahowald, N. M., Marañón, E., Marinov, I., Moore, J. K., Nakatsuka, T., Oschlies, A., Saito, M. A., Thingstad, T. F., Tsuda, A., and Ulloa, O.: Processes and patterns of oceanic nutrient limitation, Nat. Geosci., 6, 701-710, doi:10.1038/ngeo1765, 2013.

Moulin, C., Lambert, C. E., Dayan, U., Masson, V., Ramonet, M., Bousquet, P., Legrand, M., Balkanski, Y. J., Guelle, W., Marticorena, B., Bergametti, G., and Dulac F.: Satellite climatology of African dust transport in the Mediterranean atmosphere, J. Geophys. Res., 103, 13137-13144, 1998.

Moutin, T., Van Wambeke, F., and Prieur, L.: Introduction to the Biogeochemistry from the Oligotrophic to the Ultraoligotrophic Mediterranean (BOUM) experiment, Biogeosciences, 9, 38173825, doi:10.5194/bg-9-3817-2012, 2012.

Pondaven, P., Rivière, P., Ridame, C., and Guieu, C.: C, N and P stoichiometric mismatches between resources and consumers influence the dynamics of a marine microbial food web model and its response to atmospheric $\mathrm{N}$ and $\mathrm{P}$ inputs, Biogeosciences Discuss., accepted, 2014.

Prospero, J. M., Ginoux, P., Torres, O., Nicholson, S. E., and Gill, T. E.: Environmental characterization of global sources of atmospheric soil dust identified with the Nimbus 7 Total Ozone Mapping Spectrometer (TOMS) absorbing aerosol product, Rev. Geophys., 40, 1002, doi:10.1029/2000RG000095, 2002.

Pujo-Pay, M., Conan, P., Oriol, L., Cornet-Barthaux, V., Falco, C., Ghiglione, J.-F., Goyet, C., Moutin, T., and Prieur, L.: Integrated survey of elemental stoichiometry $(\mathrm{C}, \mathrm{N}, \mathrm{P})$ from the western to eastern Mediterranean Sea, Biogeosciences, 8, 883899, doi:10.5194/bg-8-883-2011, 2011.

Pulido-Villena, E., Wagener T., Guieu C., Bacterial response to dust pulses in the western Mediterranean: Implications for carbon cycling in the oligotrophic ocean, Global Biogeochem. Cy., 22, GB1020, doi:10.1029/2007GB003091, 2008.

Pulido-Villena, E., Rerolle V., and Guieu C.: Transient fertilizing effect of dust in P-deficient LNLC surface ocean, Geophys. Res. Lett., 37, L01603, doi:10.1029/2009GL041415, 2010.

Pulido-Villena, E., Baudoux, A.-C., Obernosterer, I., Landa, M., Caparros, J., Catala, P., Georges, C., Harmand, J., and Guieu, C.: Microbial food web dynamics in response to a Saharan dust event: results from a mesocosm study in the oligotrophic Mediterranean Sea, Biogeosciences Discuss., 11, $337-$ 371, doi:10.5194/bgd-11-337-2014, 2014.

Quétel, C. R.: Etude du cycle biogéochimique du fer en Méditerranée occidentale, Thèse de Doctorat de Sciences, Univ. Pierre et Marie Curie - Paris 6, 214 pp., 1991.

Quétel, C. R., Remoudaki, E., Davies, J. E., Miquel, J.-C., Fowler, S. W., Lambert, C. E., Bergametti, G., and Buat-Ménard, P.: Impact of atmospheric deposition on particulate iron flux and distribution in northwestern Mediterranean waters, Deep-Sea Res. I, 40, 989-1002, 1993.
Remoudaki, E., Bergametti, G., and Losno, R.: On the dynamic of the atmospheric input of copper and manganese into the Western Mediterranean Sea, Atmos. Environ. A, 25, 733-744, 1991a.

Remoudaki, E., Bergametti, G., and Buat-Ménard, P.: Temporal variability of atmospheric lead concentrations and fluxes over the northwestern Mediterranean Sea, J. Geophys. Res., 96, 1043$1055,1991 b$.

Ridame, C. and Guieu C.: Saharan input of phosphorus to the oligotrophic water of the open western Mediterranean, Limnol. Oceanogr., 47, 856-869, 2002.

Ridame, C., Le Moal, M., Guieu, C., Ternon, E., Biegala, I. C., L'Helguen, S., and Pujo-Pay, M.: Nutrient control of $\mathrm{N}_{2}$ fixation in the oligotrophic Mediterranean Sea and the impact of Saharan dust events, Biogeosciences, 8, 2773-2783, doi:10.5194/bg8-2773-2011, 2011.

Ridame, C., Guieu, C., and L'Helguen, S.: Strong stimulation of $\mathrm{N}_{2}$ fixation in oligotrophic Mediterranean Sea: results from dust addition in large in situ mesocosms, Biogeosciences, 10, 73337346, doi:10.5194/bg-10-7333-2013, 2013.

Ridame, C., Dekaezemacker, J., Guieu, C., Bonnet, S., L'Helguen, S., and Malien, F.: Phytoplanktonic response to contrasted Saharan dust deposition events during mesocosm experiments in LNLC environment, Biogeosciences Discuss., 11, 753-796, doi:10.5194/bgd-11-753-2014, 2014.

Sarthou, G., and Jeandel, C... Seasonal variations of iron concentrations in the Ligurian sea and iron budget in the Western Mediterranean Sea, Mar. Chem., 74, 115-129, 2001.

Shevchenko, V. P. and Lisitzin, A. P.: Aeolian Input. In Stein, R. and Macdonald, R. W. (Eds.): The Organic Carbon Cycle in the Arctic Ocean. Berlin, Heidelberg, New York, Springer-Verlag, 53-54, 2004.

Sterner, R. W.: The ratio of nitrogen to phosphorus resupplied by herbivores: Zooplankton and the algal competitive arena, Am. Nat., 136, 209-229, 1990.

Tanaka, T., Thingstad, T. F., Christaki, U., Colombet, J., CornetBarthaux, V., Courties, C., Grattepanche, J.-D., Lagaria, A., Nedoma, J., Oriol, L., Psarra, S., Pujo-Pay, M., and Van Wambeke, F.: Lack of P-limitation of phytoplankton and heterotrophic prokaryotes in surface waters of three anticyclonic eddies in the stratified Mediterranean Sea, Biogeosciences, 8, 525-538, doi:10.5194/bg-8-525-2011, 2011.

Ternon, E., Guieu, C., Loÿe-Pilot, M.-D., Leblond, N., Bosc, E., Gasser, B., Miquel, J.-C., and Martín, J.: The impact of Saharan dust on the particulate export in the water column of the North Western Mediterranean Sea, Biogeosciences, 7, 809-826, doi:10.5194/bg-7-809-2010, 2010.

Ternon, E., Guieu, C., Ridame, C., L'Helguen, S., and Catala, P.: Longitudinal variability of the biogeochemical role of Mediterranean aerosols in the Mediterranean Sea, Biogeosciences, 8, 1067-1080, doi:10.5194/bg-8-1067-2011, 2011.

Thingstad, T. F., Krom, M. D., Mantoura, R. F. C., Flaten, G. A. F., Groom, S., Herut, B., Kress, N., Law, C. S., Pasternak, A., Pitta, P., Psarra, S., Rassoulzadegan, F., Tanaka, T., Tselepides, A., Wassmann, P., Woodward, E. M. S., Wexels Riser, C., Zodiatis, G., and Zohary, T.: Nature of phosphorus limitation in the ultraoligotrophic eastern Mediterranean, Science, 309, 1068-1071, 2005 . 
Vasilkov, A., Krotkov, N., Herman, J., McClain, C., Arrigo, K., and Robinson, W.: Global mapping of underwater UV irradiances and DNA-weighted exposures using Total Ozone Mapping Spectrometer and Sea-viewing Wide Field-of-view Sensor data products, J. Geophys. Res., 106, 27205-27219, 2001.

Volpe, G., Banzon, V. F., Evans, R. H., Santoleri, R., Mariano, A. J., and Sciarra, R.: Satellite observations of the impact of dust in a low-nutrient, low chlorophyll region: Fertilization or artifact?, Global Biogeochem. Cy., 23, GB3007, doi:10.1029/2008GB003216, 2009.
Wagener, T., Guieu, C., and Leblond, N.: Effects of dust deposition on iron cycle in the surface Mediterranean Sea: results from a mesocosm seeding experiment, Biogeosciences, 7, 3769-3781, doi:10.5194/bg-7-3769-2010, 2010.

Wuttig, K., Wagener, T., Bressac, M., Dammshäuser, A., Streu, P., Guieu, C., and Croot, P. L.: Impacts of dust deposition on dissolved trace metal concentrations ( $\mathrm{Mn}, \mathrm{Al}$ and $\mathrm{Fe}$ ) during a mesocosm experiment, Biogeosciences, 10, 2583-2600, doi:10.5194/bg-10-2583-2013, 2013.

Ye, Y., Wagener, T., Völker, C., Guieu, C., and Wolf-Gladrow, D. A.: Dust deposition: iron source or sink? A case study, Biogeosciences, 8, 2107-2124, doi:10.5194/bg-8-2107-2011, 2011. 